Rev Biomed 2000; 11:135-154.

Resúmenes de Congreso

\title{
I Congreso Nacional (segunda reunión) de la Rama de Bioquímica y Biología Molecular de Virus de la Sociedad Mexicana de Bioquímica (Primera Parte).*
}

Comité Organizador:

Alejandro García-Carrancá ${ }^{1}$, Rosa Ma. del Angel ${ }^{2}$, Rafael Rivera-Torres ${ }^{3}$.

${ }^{1}$ Instituto de Investigaciones Biomédicas de la Universidad Nacional Autónoma de México, ${ }_{3}^{2}$ Centro de Investigación y de Estudios Avanzados del Instituto Politécnico Nacional, México, D.F., Centro de Investigación y de Estudios Avanzados - Irapuato del Instituto Politécnico Nacional, Guanajuato, México.

\section{CONFERENCIAS MAGISTRALES.}

\begin{abstract}
TEN YEARS OF MOLECULAR BIOLOGY AND EPIDEMIOLOGY OF HUMAN CALICIVIRUSES (HuCVs). Xi Jiang. Center for Pediatric Research, Children's Hospital of the King's Daughters, Eastern Virginia Medical School, Norfolk, VA, USA.
\end{abstract}

Research on human caliciviruses (HuCVs) has entered a molecular phase since the cloning and sequencing of the prototype Norwalk virus in 1990. Molecular charadterization of the two HuCV genera, the Norwalk-like virus (NLV) and the Sapporo-like virus (SLV) genera, allowed classification of these viruses into the Caliciviridae family. Molecular characterization also resulted in development of new diagnostic assays such as reverse transcription-polymerase chain reaction (RT-PCR) and enzyme immune assays (EIAS) based on the baculovirusexpressed $\mathrm{HuCV}$ capsid antigens. Application of these new assays in surveillance and epidemiology of HuCVs allowed description of genetic diversity and antigenic relationships among different $\mathrm{HuCV}$ strains. The importance of HuCVs as a cause of sporadic cases and outbreaks of acute gastroenteritis in children as well as general populations

\footnotetext{
* Realizado en Guanajuato, Gto., México, del 19 al 21 de Enero de 2000.
}

has been emphasized. New techniques also have been used in detection of HuCVs in environmental samples for public health safety. HuCVs still cannot be cultivated in cell cultures and passed in an animal model, which make it difficult to study the pathogenesis and host immunity following $\mathrm{HuCV}$ infection. Molecular approaches based on current understandings provide hope to overcome these diffículties. This presentation will update the current understandings and discuss future directions of $\mathrm{HuCV}$ research.

ROLE OF $\alpha 4 \beta 7$ LYMPHOCYTE INTEGRIN EXPRESSION IN ROTAVIRUS IMMUNITY. Kuklin NA, Franco M, Feng N, Wagner N, Butcher EC, Greenberg HB. Department of Microbiology and Immunology, and Department of Pathology, Stanford University School of Medicine, Stanford, U.S.A.; Institute of Genetics, University of Cologne, Germany.

Rotavirus, which replicates exclusively in the epithelium of the small intestine, is a good disease model for the study of intestinal immune responses. It is believed

Solicitud de sobretiros: Dr. Alejandro García-Carrancá, Depto. de Biología Molecular, Instituto de Investigaciones Biomédicas de la Universidad Nacional Autónoma de México, Ciudad Universitaria, Apdo. Postal 70228, C.P. 04510, México, D.F., México. 


\section{A García-Carrancá, RM del Angel, R Rivera-Torres.}

that $\alpha_{4} \beta_{7}$ integrin expression on $\mathrm{B}$ and $\mathrm{T}$ lymphocytes is required for their ability to populate the intestine. Here, using a RV mouse model and mice with targeted $\beta 7$ gene disruption ( $\beta 7-/-)$, we assessed the role of $\alpha 4 \beta 7$ integrin expression on memory $\mathrm{CD}^{+} \mathrm{T}$ cells and $\mathrm{B}$ in the resolution of rotavirus infection.

$\beta 7$-/- mice were found to have a diminished anti -RV intestinal $\lg$ A response after oral inoculation with $\mathrm{RV}$, but they cleared the infection at the same time (day 7) as wild type (wt) animals. Depletion of $\mathrm{CD}^{+} \mathrm{T}$ cells prolonged the viral shedding of $\beta 7-/-$ animals, indicating that $\beta 7-/-$ $\mathrm{CD}^{+} \mathrm{T}$ cells are involved in controlling the primary infection as they are in wt animals. Moreover $\beta 7-/-\mathrm{CD}^{+}$ $T$ cells (isolated from orally immunized $\beta 7$-/- donor mice and lacking both $\alpha 4 \beta 7$ and $\alpha_{E} \beta 7$ integrin expression) were able to migrate to the intestine and resolve RV infection with the same kinetics as wt $\mathrm{CD}^{+} \mathrm{T}$ cells when transferred into chronically infected Rag-2 $\mathrm{KO}$ mice. The time of appearance of the transferred $\mathrm{CD}^{+} \mathrm{T}$ cells (both $\beta 7$-/and wt) in the intestinal epithelium correlated with the time of resolution of the RV infection. On the other hand, $\beta 7$-/- immune B cells were unable to clear chronically infected Rag-2 mice after transfer. These results indicate that $\beta 7$ expression is not an absolute requirement for the anti RV function of $\mathrm{CD}^{+} \mathrm{T}$ cells and that other molecules are capable of directing and/or retaining immune $\mathrm{CD}^{+} \mathrm{T}$ cells to intestine. $\beta 7$ expression does, however, appear to be an absolute requirement for $\mathrm{B}$ cell effector function in this model.

\section{PROBING GEMINIVIRUS-HOST INTERACTIONS WITH A GREEN FLUORESCENT PROTEIN REPORTER SYSTEM. Gilbertson $R$.}

Geminiviruses (Family Geminiviridae) are small plant viruses that possess a single-stranded DNA genome encapsidated within twinned icosahedral virions. In nature, geminiviruses are spread via certain species of whiteflies or leafhoppers. In tropical and subtropical regions, a diversity of whitefly-transmitted geminiviruses (Genus Begomovirus) infect crops such as tomato, pepper, melons, and beans and, over the past 10-15 years, these viruses have emerged as major constraints on crop production. However, because geminiviruses have a small DNA genome (2.5-5.0 $\mathrm{kb})$ and replicate within nuclei as circular double-stranded DNAs, they are attractive tools for studying DNA replication, gene expression and macromolecular trafficking in plants. In this presentation, the development of a bean dwarf mosaic virus (BDMV; a 'typical bipartite begomovirus)-green fluorescent protein (GFP) reporter system will be described. The BDMV-GFP system has been used to study viral cell-to-cell and long-distance movement in a susceptible common bean cultivar, and to essentially follow the viral infection process from the seeding stage throughout the entire life cycle of the plant. These studies revealed the capacity of the virus to move cell-to-cell in phloem and non-phloem cells, and that the stage of plant development influenced the capacity of the virus to exit phloem tissues. Long-distance movement followed a sourcesink pattern, with phloem progenitor cells (i.e., protophloem) in the shoot apex appearing to play a critical role in the infection process. BDMV-GFP infected flower, pod, and seed-coat tissues but was excluded from the embryo, consistent with the lack of seed transmission of geminiviruses. The BDMV-GFP reporter was then used to analyze the basis of BDMV resistance in cvs. Othello and Black Turtle Soup (BTS). In both cvs., resistance was due to a block in long-distance transport and, for cv. Othello but not BTS, resistance was associated with development of a hypersensitive response (HR) in the phloem. Through the use of pseudorecombinant viruses, the viral determinant (i.e., avirulence factor) of the resistance/HR was mapped to the BDMV DNA-B component. Fine mapping of this factor is being carried out through the use of a series of hybrid DNA-B components containing sequences of BDMV and bean golden mosaic virus, which systemically infects cvs. Othello and BTS.

\section{DIAGNOSING FLAVIVIRUS INFECTIONS IN ENDEMIC AREAS OF AFRICA: THE CONTINUED PROBLEM OF ANTIGENIC CROSS-REACTIVITY. BABA SS. Virology Lab., Dept. of Experimental Pathology, CINVESTAV-I.P.N., Mexico City, Mexico.}

The genus flavivirus Family (Flaviviridae) contains some 70 closely related human and veterinary pathogens causing many serious íllnesses. Most members of the group are arthropod borne. Prior exposure to some members of the group might modify the course of infections with other flaviviruses. Despite vígorous attempts to resolve the antigenic relatedness of this group of viruses, inconsistent and unexpected results are usually obtained in serological assays even with monoclonal antíbodies. The little information available on the genetícs of members of the group is yet to resolve the problem of flavivirus nucleic, acid and antigenie cross-relationships. The implications of this phenomenon for the pathogenesis, diagnosis, prevention and control of flaviviruses in endemic areas are discussed in this presentation.

UNDERSTANDING THE MECHANISM OF REPLICATION AND PATHOGENESIS OF HEPATITIS C VIRUS. Michael M. C. Lai, Howard Hughes 


\section{Congreso Nacional de Bioquímica y Biología Molecular de Virus.}

Medical Institute and Department of Molecular Microbiology and Immunology, University of Southem Califomia School of Medicine, Los Angeles, California 90033 USA.

Hepatitis $\mathrm{C}$ virus (HCV) is a major cause of chronic hepatitis, liver cirrhosis and hepatocellular carcinoma world-wide. Due to the lack of cell culture systems and small animal models for $\mathrm{HCV}$, the mechanisms of viral replication and pathogenesis are poorly understood. HCV is characterized by the high frequency of persistent infection; the available options for therapy are limited to ínterferon and ribavírin, which-are not very effective. Our recent studíes have yielded several new insights into the mechanisms of HCV replication, persistence and pathogenesis, offering possible strategies for improved therapíes. We found that the HCV envelope protein E2 shares sequence homology with the interferon-induced, doublestranded RNA-activated protein kinase PKR and its target protein eIF- $\alpha$ and inhibits PKR activity through the mechanism of molecular mimicry. Since PKR is the major mediator of interferon actions, this effect may account for the resistance of $\mathrm{HCV}$, (particularly genotype 1, which has the highest extent of sequence homology to PKR), to interferon. This sequence homology can potentially be used to improve the effícacy of interferon therapy.

The replication of HCV RNA is carried out by the viral ns $5 b$ protein, RNA-dependent RNA polymerase. We have expressed a functionally active recombinant $n s 5 b$, which can perform primerindependent RNA synthesis, copying the entire HCV RNA. This polymerase has provided the opportunity to understand the mechanism of HCV replication and also provides a promising target for the development of antiviral agents. Fínally, we and several other laboratories have identified cellular proteins that interact with viral proteíns, such as core and ns5a. These interactions lead to the disruption of normal cellular functions and the alteration of cellular responses to viral infections, thus contributing to viral pathogenesis. These various facets of $\mathrm{HCV}$ infections will be discussed.

\section{TRABAJOS LIBRES.}

ESTUDIO COMPARATIVO DE LA SEROEPIDEMIOLOGÍA DE LA INFECCIÓN POR ROTAVIRUS Y CALICIVIRUS HUMANOS EN NIÑOS MEXICANOS. ${ }^{1}$ VELÁZQUEZ FR, ${ }^{2}$ JIANG $X,{ }^{1}$ CANSECO RG, ${ }^{1}$ GALVAN ML, ${ }^{1}$ BUSTAMANTE ME, ${ }^{3}$ TAPIA-CONYER R, ${ }^{1}$ TORRES J, ${ }^{1}$ MUÑOZ O. ${ }^{1} \mathrm{U}$. Investigación Médica en Enfermedades Infecciosas y Parasitarias, Hospital de Pediatría, CMN-SXXI, IMSS, ${ }^{2}$ Center for Pediatric
Research, Eastern Virginia Medical School, VA, USA, ${ }^{3}$ Dirección General de Epidemiología, SSA, México, D.F., México.

Introducción: El rotavirus humano del grupo A (RV) es la causa principal de diarrea grave en niños $<5$ años en todo el mundo. Los calicivirus Norwalk (VN) y México (MX) son cepas representativas de 2 de los 3 genogrupos de calicivirus humanos (CV), que son causa de brotes de diarrea aguda. Es necesario conocer los factores de riesgo para la infección por RV y CV en nuestro país, para promover medidas de prevención adecuadas.

Objetivo: Comparar la seroprevalencia y características sociodemográficas asociadas como factores de riesgo para adquirir la infección por RV y CV en niños menores de 5 años de la República Mexicana.

Métodos: Una muestra de 1, 123 niños menores de 5 años de edad, representativa de dicho grupo de edad a nivel nacional, fue seleccionada de manera aleatoria y probabilística de la Encuesta Nacional Seroepidemiológica, realizada de marzo de 1987 a mayo de 1988. Las muestras de suero fueron probadas para la presencia de anticuerpos IgG específicos contra RV, VN y MX, mediante ensayo imnunoenzirnático.

Resultados: La prevalencia nacional de anticuerpos específicos contra RV, VN y MX en niños menores de 5 años fue semejante (93\%). La seroprevalencia de RV en niños de un año de edad fue de $87 \%$, comparada con $74 \%$ para VN $(\mathrm{P}=.03)$. Un incremento similar en la seroprevalencia de RV y CV de $95 \%$ se alcanzó a los 3 años de edad $(\mathrm{P}=.03)$. El sexo masculino fue un factor de riesgo para la infección por $\mathrm{RV}(\mathrm{P}=.02)$, pero no para $\mathrm{CV}$. La infección por $\mathrm{CV}$ fue más común en áreas rurales $(\mathrm{P}=.008)$, pero la infección por $\mathrm{RV}$ fue similar en áreas urbanas y rurales. La reducción del hacinamiento $(\mathrm{P}=.003)$, la mejoría de las condiciones de la vivienda $(\mathrm{P}=.02)$ y del nivel socioeconómico $(\mathrm{P}=.02)$ se asociaron con un menor riesgo de infección por $\mathrm{CV}$, pero no de infección por RV.

Conclusiones: La infección por RV y CV es frecuente en niños mexicanos, sobretodo durante los 3 primeros años de vida. La infección por RV ocurre más tempranamente que la infección por VN. El mejoramiento de las condiciones de higiene, saneamiento ambiental y del nivel socioeconómico podrían influir en la prevención de la infección por CV. Sin embargo, estas mismas medidas no parecen ser suficientes para la prevención de la infección por RV y es probable que se requiera de una vacuna eficaz para intentar su control.

EVENTOS MOLECULARES IMPLICADOS EN LA REPLICACIÓN DEL VIRUS NORWALK. Uríbe-Brito

Vol. 11/No. 2/Abril-Junio, 2000 


\section{A García-Carrancá, RM del Angel, R Rivera-Torres.}

Z., del Angel, R. M. y Gutiérrez-Escolano A. L. Depto. de Patología Experimental. CINVESTAV, México, D.F., México.

El virus Norwalk (NV) es responsable de al menos $50 \%$ de las epidemias de gastroenteritis no bacterianas en el mundo. Es un virus esférico de $27 \mathrm{~nm}$ de diámetro que carece de envoltura. Su genoma es una molécula de RNA de cadena sencilla y polaridad positiva con un tamaño de $7.6 \mathrm{~kb}$ que carece de estructura "cap". Posee 3 marcos de lectura abiertos (ORF), el primero codifica para las proteínas no estructurales, las cuales presentan una gran homología con las de los picornavirus.. El segundo y el tercero se localizan en un RNA subgenómico a partir del cual se asume que se sintetiza la única proteína de la cápside. En el extremo $5^{\prime}$ de cada uno de los ORF se localiza una estructura de doble tallo y burbuja similar a las involucradas en la regulación de la replicación de otros virus. Para saber el papel de dicha estructura en la replicacíón de NV hemos inicialmente analizado su interacción con proteínas celulares. Mediante ensayos de retardamiento detectamos la formación de complejos ríbonucleoprotéicos (CRNP) específicos y estables con proteínas de células HeLa y CaCo-2. Además por ensayos de entrecruzamiento hemos determinado que los pesos moleculares de estas proteínas son semejantes a los de las proteínas que participan en la traducción de poliovirus (PV). Por ultimo, mediante ensayos de superretardamiento estamos identificando a las proteínas que forman estos CRNP, habiendo encontrado que éstas son compartidas entre ambos virus. Estos resultados podrían sugerir que algunos de los mecanismos de replicación de PV y NV son similares.

DIVERSIDAD GENÉTICA DE LAS CEPAS ROTAVIRUS ASOCIADAS CON DIARREA AGUDA. Ramírez González JE, Rodríguez Castillo A, Melo Munguía M, Díaz de Jesús B, Mayén Pimentel E y García Lozano H. Laboratorio de Rotavirus del Instituto Nacional de Diagnóstico y Referencia Epidemiológicos (INDRE). Carpio \# 470, Col. Sto. Tomás, México, D.F.

Los rotavirus del grupo A se clasifican en genotipos con base en los genes que codifican para las dos proteínas de cápside externa, genotipos G para VP7 y genotipos $\mathrm{P}$ para VP4. Los genotipos Gl-G4 Pl-P5 son los epidemiológicamente más importantes en seres humanos. Actualmente se efectúa un sistema binario de clasificación involucrando la combinación de ambas proteínas (GP), de esta manera tenemos que las cepas con genotipo GlPl, G2P2 y G3Pl son las que se presentan con mayor frecuencia en el mundo. Otra clasificación esta relacionada con la migración electroforética del genoma viral teniendo así, patrones electroforéticos (pe) largos y pe cortos. El objetivo de este proyecto fue determinar la diversidad genética de las cepas de rotavirus asociadas a cuadros diarreicos en México. De un banco de 4,235 muestras positivas a rotavirus, se analizaron 308 procedentes de diferentes lugares de la República Mexicana. Se utilizaron técnicas moteculares como la RT-PCR utilizando oligonucleótidos específicos para los genotipos Gl -G4 (VP7) y Pl-P5 (VP4), y la técnica de PAGE al 10\% para el análisis del genoma viral. El análisis independiente de los genes de VP7 y VP4 reveló la circulación de los genotipos G1, G2, G3 y P1, P2, P3 respectivamente, siendo Gl (48\%) y $\mathrm{Pl}(61 \%)$ los que se presentaron con mayor frecuencia. Al realizar las combinaciones genotípicas para cada aislado y obtener un sistema bínario de nomenclatura, encontramos la circulación de 8 genotipos, destacando G1Pl (36.7\%), G3Pl (17.5\%) y G2P2 (16.2\%), además identificamos infecciones mixtas (11.7\%) poco comunes. El análisis del genoma viral, mostró la circulación de los dos pe (largo y corto), sin embargo se observó una variación determinada por pequeños cambios en la migración de los segmentos del genoma entre las cepas que tienen e mismo pe y, por otra parte, el hallazgo de 5 cepas denominadas como patrones electroforéticos atípicos con genotipo GlPl, observándose en tres de estas cepas variaciones electroforéticas considerables del segmento $8 \mathrm{y}$ en las dos restantes variaciones del segmento 11 . Con estos resultados podemos confirmar la diversidad de cepas de rotavirus que circulan en nuestro país además de considerar la importancia de este tipo de estudios para la valoración de una vacuna.

POLIMORFISMO GENÓMICO EN LAS CEPAS DE ROTAVIRUS ASOCIADAS CON DIARREA. Herlinda García-Lozano, Benita Díaz de Jesús, Araceli Rodríguez Castillo, Elvira Mayén Pimentel, Ernesto Ramírez González, Angel A. Barney, Lízbeth Teran Vega, Paula Servín Villa, Yarazeth A. Juárez y Martín Melo Munguía. Laboratorio de Rotavirus del Instituto Nacional de Diagnóstico y Referencia Epidemiológicos SSA. (INDRE).Carpio 470, Col. Sto. Tomás. México D.F., México.

La diarrea por rotavirus representa un problema de salud pública en todo el mundo. La serotipificación de los aislamientos clínicos ha permitido conocer la epidemiología de este padecimiento. Sin embargo, la separación electroforética del genoma viral (electroferotipificación) ha sido utilizada como un método alternativo para la caracterización de cepas de campo en estudios epidemiológicos. Por lo que el objetivo del trabajo es analizar el polimorfismo genómico que se presenta en las cepas de 


\section{Congreso Nacional de Bioquímica y Biología Molecular de Virus.}

campo asociadas con brotes diarreicos en niños mexicanos. Se analizaron 4,235 muestras fecales positivas a rotavirus de pacientes menores de 5 años con diarrea aguda de diferentes zonas geográficas de la República Mexicana durante 5 años (1994-1999). El dsRNA genómico fue extraído con fenol-cloroformo y purificado por la técnica de CF-11. Se analizaron los electroferotipos por la técnica de PAGE al $10 \%$ teñido con nitrato de plata. La tipificación a VP7 se realizó por la técnica de RT-PCR con los oligonucleótidos específicos de serotipo. Los resultados fueron los siguientes: De un total de 4,235 muestras positivas a rotavirus se identificaron 31 electroferotipos distintos, 14 asociados al serotipo G1, 10 a G3, 9 a G2 y ninguno a G4. Se observaron 23 electroferotipos largos y 10 electroferotipos cortos. Los estudios de electroferotipificación permiten analizar las cepas que predominan o circulan en un brote, grupos, cambios secuenciales de los perfiles genómicos, rearreglos genéticos, movimiento y desplazamiento de los electroferotipos en una región y tiempo determinado.

ROTAVIRUS COMO CAUSA DE DIARREA GRAVE EN LA ERA PREVACUNAL EN MEXICO. Velázquez FR, Castellanos A, Luna G, Domínguez A, Bustamante ME, Cedillo R, Torres J, Muñoz O. Unidad de Investigación Médica en Enfermedades Infecciosas y Parasitarias, Hospital de Pediatría, CMN-SXXI. México, D.F., México.

Introducción: La vacuna tetravalente contra rotavirus (TVRV) ha sido licenciada en EUA y en breve estará disponible en México. No existen estudios que determinen la participación actual de rotavirus (RV) como causa de diarrea grave, los cuales son necesarios para evaluar el impacto que esta vacuna tendría en la prevención de diarrea grave en niños mexicanos.

Objetivos: Determinar la proporción de diarrea grave causada por RV y describir sus características epidemiológicas en niños $<5$ años de edad. Estimar el impacto potencial que un programa de vacunación contra RV tendría sobre las enfermedades diarreicas en niños mexicanos.

Métodos: Estudio transversal, prolectivo y multicéntrico, realizado de marzo 1998 a febrero 1999, en tres hospitales de la Cd. de México. Se reclutaron niños < 5 años de edad hospitalizados por diarrea. La gravedad del episodio se calificó con una escala semi-cuantitativa. Se midieron variables para evaluar la alimentación, los hábitos de higiene y el nivel socioeconómico. El RV se detectó por ELISA en muestras fecales colectadas al ingreso. La eficacia de la vacuna TV-RV se consideró de estudios previamente publicados.

Resultados: Se reclutaron 399 niños hospitalizados por diarrea. RV se detectó en 178 (45\%) casos, de los cuales, $80 \%$ ocurrieron durante los $0-18$ meses de edad $(\mathrm{P}<001)$ y $85 \%$ durante la temporada de otoño-inviemo (O$\mathrm{I} ; \mathrm{P}<001)$. La gravedad de la diarrea por RV fue mayor comparada con la no asociada a RV $(\mathrm{P}<.001)$. La alimentación al pecho materno $(\mathrm{P}=.01)$, el mejoramiento de los hábitos de higiene $(\mathrm{P}<.01)$ y del nivel socioeconómico $(\mathrm{P}<.01)$, mostraron mayor probabilidad de disminuir el riesgo de diarrea grave no asociada a RV. Considerando una eficacia de la vacuna TV-RV de $88 \%$ en contra de episodios graves por RV, un programa de vacunación universal contra RV podría evitar 39\% de todas las hospitalizaciones debidas a diarrea en niños $<5$ años. Conclusiones: RV es causa frecuente de hospitalización por diarrea grave. La alimentación al pecho materno, el mejoramiento de los hábitos de higiene y del nivel socioeconómico no parecen ser medidas suficientes para su prevención. La vacunación universal contra RV es una alternativa que podría prevenir un alto porcentaje de episodios graves de diarrea que condicionan hospitalización. Esta vacuna deberá ofrecerse a edad temprana y antes de la temporada de O-I. Se requieren estudios de costo-beneficio que confirmen la conveniencia de implementar un programa de vacunación universal contra RV en México.

ANÁLISIS DE LA VARIABILIDAD GENÉTICA DEL GEN DE VP7 EN CEPAS DE ROTAVIRUS DEL GRUPO "A" GENOTIPO G1PI. Rodríguez Castílo A. Ramírez González E, Mayén Pimentel E, Melo Munguía M, Díaz de Jesús B, y García Lozano H. Laboratorio de Rotavirus, Instituto Nacional de Diagnóstico y Referencia Epidemiológicos (INDRE), Secretaría de Salud, México D.F., México.

Las proteínas de cápside externa VP4 y VP7 son las que interactúan con la célula blanco, participan en la infección e inducen la formación de anticuerpos neutralizantes de manera independiente, permitiendo clasificar a las cepas en serotipos y genotipos P(VP4) y G (VP7). La caracterización completa de los rotavirus del grupo A, requiere de una clasificación dual de genotipos (GP), siendo la cepa G1Pl la de mayor circulación a nivel mundial. La finalidad de este trabajo fue analizar la variabilidad de los genes que codifican para las proteínas VP4 y VP7 de cepas de rotavirus humanos del grupo "A" genotipo G1Pl. La metodología fue la siguiente: 1 . Selección de muestras positivas a rotavirus de niños con gastroenteritis aguda procedentes del Hospital Infantil de México (HIM), durante el periodo de Oct-95 a Oct-98. 2. Extracción y purificación del RNA viral. 3. RT-PCR. 4. RFLP de las cepas Gl.Pl. 5. PAGE al 10\%. Los resultados 


\section{A García-Carrancá, RM del Angel, R Rivera-Torres.}

obtenidos fueron de un total de 297 muestras positivas a rotavirus se seleccionaron 116 , las cuales fueron tipificadas a genotipos G y P. Se encontraron 60 cepas $(51.7 \%)$ con genotipo G1Pl. El análisis del producto de amplificación del gen de VP7 con endonucleasas de restricción (Hae III, Taq I, Rsa I y Pvu II), mostró la presencia de 3 patrones de restricción con Hae III, 6 con Taq I, 10 con Rsa I, y 2 con $P v u$ II. Los patrones de restricción con la combinación de endonucleasas permitió la agrupación en 18 perfiles de restricción diferentes, denominados REA1-REA18. Los perfíles más comunes fueron el REA-1 que se observó en $21(35.0 \%)$ cepas y el REA-11 en $14(23.3 \%)$ cepas, mientras que el resto de las cepas $25(41,7 \%)$ fueron altamente heterogéneas. Es importante destacar que todas las cepas de estudio tienen un sitio conservado en el nucleótido 381 con Hae III, en el 786 con Taq I y en el 780 con $R s a-I$ y que las cepas con perfil REA-1 y REA-11 difieren sólo en un corte con Taq-I en el nucleótido 1049 del gen de VP7. Finalmente, el análisis de electroferotipos demostró la circulación de 4 electroferotipos distintos en las cepas analizadas, por RFLP, sin encontrar una correlación entre el patrón de restricción y el electroferotipo de las cepas de estudio.

\section{LA PROTEINA DE CHOQUE TERMICO HSC70 ESTA INVOLUCRADA EN LA ENTRADA A LA CELULA DE LOS ROTAVIRUS. Guerrero CA, Isa, P, Méndez, E, López S. y Arias CF. Instituto de Biotecnología, UNAM. Cuernavaca, Mor., México.}

Demostramos que el detergente $\beta$-octilglucósido puede extraer de la superficie de las células MAl04, susceptibles a la infección por rotavirus, proteínas que son capaces de interaccionar con el virus en solución y bloquear su infectividad. Mediante electroforesis preparativa del extracto de $\beta$-octilglucósido, se aislaron cinco bandas de aproximadamente $110,75,57,45$ y $30 \mathrm{kD}$, con la capacidad de inhibir la infección de rotavirus. Determinamos la secuencia de aminoácidos de cuatro péptidos derivados de la banda de $75 \mathrm{Kda}$ (la cual mostró la más alta actividad inhibitorio específica). La secuencia de dos de los péptidos coincidió en $100 \%$ con la proteína hsc7O, que es la forma constitutiva de la proteína que se induce por choque térmico, hsp7O. Los otros dos oligopéptidos mostraron una identidad del $90 \%$ con la proteína $\alpha$-actinina. Anticuerpos específicos contra hsc7O inhibieron la infectividad de varias cepas del rotavirus, cuando se preincubaron con las células antes de añadir el virus. Estos anticuerpos no inhibieron la entrada de poliovirus ni de reovirus. Igualmente, anticuerpos contra $\alpha$-actinina no inhibieron la infectividad de los rotavirus. Mediante citometría de flujo, inmunofluorescencia y biotinilación de las proteínas de membrana, se pudo determinar que la proteína hsc70 se encuentra en la superficie de las células MA104. La incubación de hsc7O purificada (1 $\mu \mathrm{g} / \mathrm{ml})$ con los rotavirus inhibió aproximadamente $50 \%$ de su infectividad. Esta interacción se corroboró mediante un ensayo de ELISA.

EL DOMINIO C-TERMINAL DE LA PROTEÍNA NSP5 DE LOS ROTAVIRUS ES ESENCIAL EN SU MULTIMERIZACIÓN, HIPERFOSFORILACIÓN E INTERACCIÓN CON NSP6. Torres-Vega MA, González RA, López S, Arias CF. Instituto de Biotecnología, UNAM, México, D.F., México.

Los rotavirus, considerados como el principal agente de la diarrea en niños y animales jóvenes, están formados por tres capas concéntricas de proteína, que envuelven un genoma de 11 segmentos de RNA de doble cadena. El genoma codifica para seis proteínas estructurales y para seis proteínas no estructurales. Entre éstas últimas está la NSP5, que aparentemente tiene actividad de autofosforilación, y que se encuentra en células infectadas como varias isoformas con Mr de 26, 28 y 30-34 kDa. La NSP5 se localiza en los viroplasmas y está asociada con partículas subvirales que funcionan como intermediarios en la replicación de los rotavirus. Nuestro grupo ha determinado que la NSP5 forma oligómeros e interacciona con otra proteína no estructural, la NSP6, en células de levadura. En este trabajo identificamos los dominios de NSP5 que están involucrados en estas asociaciones. Para ello construímos mutantes de deleción de NSP5 que ensayamos en su habilidad para interaccionar con la NSP5 y la NSP6 silvestres, usando el sistema de los dos híbrídos de levadura. El dominio de homomultimerización fue localizado en los últimos 20 aminoácidos del extremo carboxilo, que es una región altamente conservada de la proteína, y por predicción tiene una estructura de alfa-hélice. El dominio de interacción con NSP6 abarca los 35 aminoácidos carboxi-terminales de NSP5, por lo cual se yuxtapone con el dominio de homomultimerización. La homo-oligomerización de NSP5 y la formación de complejos con NSP6 fue también observada por medio de un ensayo de afinidad in vitro, y por inmunoprecipitación de los complejos de proteína sintetizados transitoriamente y ensamblados en células MA104. El empleo de una mutante de:NSP5 que carece de los últimos 10 aminoácidos de la proteína, en los diferentes sistemas utilizados, permitió i) verificar los dominios de homo-oligomenzación e interacción con NSP6; ii) observar una correlación entre la homo-oligomerización de NSP5 y su capacidad de hiperfosforilación (isoformas de 30-34 kDa) y de formación de estructuras similares a viroplasmas. Proponemos que la homo-oligomerización de NSP5 


\section{Congreso Nacional de Bioquímica y Biología Molecular de Virus.}

determina sus propiedades, con NSP6 participando como uno de los reguladores.

EL ANTICUERPO MONOCLONAL 2D9, EL CUAL BLOQUEA LA INFECCIÓN DE LAS CÉLULAS POR ROTAVIRUS, RECONOCE UNA PROTEÍNA PARECIDA A VIMENTINA. Isa P, Espinosa R, Lopez S, Arias CF. Instituto de Biotecnología, Universidad Nacional Autónoma de México, Cuernavaca, México.

Los rotavirus son el principal agente de gastroenteritis viral en niños menores de dos años. El tropismo celular de los rotavirus es específico, infectando únicamente enterocitos maduros del intestino delgado in vivo. In vitro, los rotavirus son capaces de unirse a una gran variedad de líneas celulares, pero infectan solamente líneas de origen renal (p. ej. MA104) o intestinal. Estas observaciones sugieren la presencia de un receptor específico en dichas líneas celulares. Anteriormente describimos el aislamiento de un anticuerpo monoclonal (AcM) 2D9, dirigido contra la superficie de las células MA104, que bloquea la infección por rotavirus RRV y el variante RRVnar. Utilizando un ensayo de inmunoaislamiento en fase sólida (SPIT), el AcM 2D9 reconoce una proteína de aproximadamente $55 \mathrm{kDa}$, la cual en algunos casos esta acompañada por otras proteínas de aproximadamente 45 y $220 \mathrm{kDa}$. Dos fragmentos de la proteína de $55 \mathrm{kDa}$ fueron secuenciados y ellos presentan $100 \%$ de identidad con vimentina, una proteina de filamentos intermedios. En experimentos subsequentes demostramos que: 1. El AcM 2D9 reconoce, mediante un ensayo de ELISA, a vimentina bovina comercial y vimentina humana expresada en bacterias. 2. Un anticuerpo monoclonal específico para vímentína (V9) reconoce la superficie de las células MA104 mediante citometría de flujo (FACS). 3. Los AcMs V9 y 2D9 permiten purificar el mismo complejo de proteínas por un ensayo en fase sólida. 4. El AcM V9 y los anticuerpos policlonales contra vimentina no bloquean la infectividad de los rotavirus. 5. Vimentina humana expresada en bacterias no bloquea la infectividad de los rotavirus. 6. El AcM 2D9 reconoce la superficie de las células SW13 (las cuales expresan vimentina) y las células SW-13 clona 2 (las cuales no expresan vimentina).

Estas observaciones sugieren que el AcM 2D9 reconoce, además de vimentina, otra molécula parecida a vimentina, la cual no ha sido identificada, y la cual es responsable de interaccionar con los rotavirus en la superficie de la célula.

LA PROTEINA NSP3 DE ROTAVIRUS ABATE LA SINTESIS DE PROTEINAS EN CELULAS DE
MAMIFERO. Padilla-Noriega L., Paniagua-Taboada O, Guzmán-León S. Depto. de Biología Molecular, Inst. de lnvest. Biomédicas, UNAM, México, D.F., México.

Los rotavirus del grupo A son el principal agente etiológico de gastroenteritis aguda infantil. El genoma viral consta de 11 segmentos de RNA, de cadena doble, los cuales codifican por 6 proteínas estructurales y 6 proteínas no estructurales. Los viriones tienen actividad de RNA transcriptasa, produciendo RNAM con cap en su extremo 5', y la secuencia UGACC no poliadenilada en su extremo 3'. La proteína viral no estructural NSP3 es análoga a la proteína celular PABP, ya que se une al factor de iniciación de traducción elF4G, pero esta unión sólo se da si PABP se une simultáneamente al extremo 3' poli-A del RNAM celular, mientras que NSP3 lo hace independientemente de su capacidad para unirse al extremo 3' UGACC del RNAM viral. En base a estas propiedades NSP3 podría estimular la traducción de los RNAM virales, y hacer a el F4G inaccesible a los RNAM celulares. Para abordar estas interrogantes hemos expresado en forma inducible la proteína NSP3 del rotavirus RRV en un vector del virus vaccinia, incorporando al RNAM de NSP3 la región líder del virus de encefalomiocarditis (EMC) para hacer eficiente su expresión. Se logró la expresión regulada de NSP3 en células de mamífero, y concomitantemente se abatió drásticamente la síntesis de proteínas celulares y de vaccinia. Concluimos que NSP3 es capaz de abatir la síntesis de proteínas en células de mamífero, excepto si el RNAM presenta el mecanismo alterno de iniciación de traducción del virus EMC.

DETECCIÓN DE VIRUS SUBTIPO B DEL HIV-1, MEDIANTE EL ANÁLISIS DE RESTRICCIÓN DE AMPLICONES DE gag CON LA ENZIMA Bst Xi (REA-PCR). Gudiño JC, Soler C. Unidad de Investigación en Retrovirus Humanos. UNAM-SSA, México, D.F., México.

Introducción: La amplificación de DNA, seguida de cortes con enzimas de restricción puede ser una alternativa útil para genotipificación rápida del HIV.

Objetivo: Detectar la presencia de virus del subtipo B en muestras de DNA de individuos infectados, por el corte de amplicones de la región gag del HIV-1 con enzimas de restricción.

Metodología: Primero se amplificó el gen de globina humana como control de calidad del DNA. El gen gag del HIV se amplificó por PCR anidado con los iniciadores: gag 5' 1: 5'-tccacctatcccagtaggag; gag 3' 1: 5'ggtcgttgccaaagagtgat, (nucleótidos 1547 a 2260 de la secuencia HXB2) y gag 5' 2:taaaagatggataatcctggg; gag 3'

Vol. 11/No. 2/Abril-Junio, 2000 
A García-Carrancá, RM del Angel, R Rivera-Torres.

2: gccaaagagtgatctgaggg, (1574 a 2221 de HXB2). Finalmente los amplicones de gag se cortaron con Bst Xi y se visualizaron en electroforesis en gel de agarosa.

Resultados: Mediante el análisis teórico de secuencias publicadas se seleccionó la enzima Bst XI, la cual corta la secuencia de gag elegida en el $80 \%$ de los virus del subtipo B de la base retrovirus de Los Alamos. Se estudiaron 105 muestras de DNA, todas resultaron positivas a la amplificación del gen de globina humana, lo cual asegura la calidad de las muestras. De ellas, 97 (92\%) resultaron Positivas a la amplificación de gag. Los amplicones se sometieron a restricción con Bst Xi y 88 (91 \%) presentaron e1 sitio de corte mientras que $9(9 \%)$ no se cortaron con esta enzima.

Conclusión. La amplificación de la región de gag por PCR anidado, seguida del análisis de corte con Bst Xi permitió determinar el subtipo genético (B) en el $91 \%$ de muestras de DNA de individuos, infectados con el HIV. Esta metodología permite hacer un tamizaje de muestras, para optimizar los recursos y aquellas cuyo subtipo no puede ser determinado de se pueden analizar con metodologías más complicadas para conocer su genotipo.

\section{IDENTIFICACION DEL GENOMA DEL VIH EN PERSONAS SERONEGATIVAS CON EXPOSICION REPETIDA AL VIRUS. Góngora-Biachi, RA, Valadez- González N, González-Martínez P, Castro-Sansores C. Centro de Investigaciones Regionales "Dr. Hideyo Noguchi", Universidad Autónoma de Yucatán, Mérida, Yucatán, México.}

Introducción. El diagnóstico de la infección por el virus de la inmunodeficiencia humana se basa en la identificación de anticuerpos específicos. En algunos casos la emergencia de Ac ocurre hasta 42 meses posteriores a la infección, por lo que en los casos de personas expuestas y seronegativas al VIH la identificación del genoma viral en células mononucleares es un método útil para diagnosticar la infección por VIH.

Objetivo. Detectar el genoma de VIH mediante PCR en células mononucleares de sangre periférica en personas negativas que se han expuesto repetidamente al virus.

Métodos. Se estudiaron a 18 sujetos seronegativos cuyos compañeros sexuales tenían la infección por el VIH (4 (22\%) hombres y 14 (78\%) mujeres. Se obtuvo una muestra de sangre y se realizó extracción de DNA Para el ensayo de PCR se utilizó el par de iniciadores SK145/431 y Gag 1-2 que amplifica 2 regiones del gen gag del VIH.

Resultados. La edad promedio del grupo estudiado fue de $32(18-44)$ años. En seis (33\%) sujetos se pudo detectar el genoma del VIH con por lo menos un par de iniciadores, 2 muestras (11\%) amplificaron con los dos iniciadores; y 4
(22\%) sólo amplificaron con Gag 1-2. En 11 muestras se realizó detección del Ag-p24., obteniéndose un caso positivo. No se encontraron diferencias significativas entre los positivos al relacionar el tiempo de exposición previo y posterior al diagnóstico ni con el estado clínico al momento del diagnóstico.

Conclusiones. En 33\% de sujetos seronegativos expuestos al virus se identificó el genoma del VIH. El uso de iniciadores Gag 1-2 aumenta la sensibilidad de la PCR. La PCR en un método útil para detectar oportunamente la infección en personas expuestas a la infección por el VIH.

CARACTERIZACIÓN INMUNOLÓGICA Y VIROLÓGICA DE PACIENTES HIV-1 SEROPOSITIVOS DE LARGA SOBREVIDA. Gómez-Román VR, Vázquez JA, Basualdo MC, Gudiño JC, Wong C, Cruz G, Adalid LV, Estrada J, Ramos M, Soler C. Unidad de Retrovirus Humanos. UNAM, SSA y Universidad Panamericana. México, D.F., México.

Desde 1995, hemos estudiado a un grupo de 11 pacientes mexicanos infectados más de 10 años con el virus de la inmunodeficiencia humana tipo 1 (HIV-l). Mediante ensayos de movilidad de heteroduplex (HMA) y secuenciación de la región terminal repetida larga (LTR), hemos confirmado que los virus que portan estos pacientes corresponden al Subtipo B. En los virus de 4 pacientes asintomáticos (linfocítos $\mathrm{T} \mathrm{CD}^{+}>450 \mathrm{cels} / \mathrm{mm}^{3}$ ), observamos mutaciones puntuales en el elemento regulatorio de transactivacióri (TA mientras que en el virus de un paciente con diagnóstico de SIDA, identificamos una deleción de 18 pp dentro del sitio NFAT-1. Esta delecíón coincide con un nivel bajo de replicación viral in vivo (carga viral $<500$ copias/ml plasma) e in vitro (aislamiento viral negativo). Asimismo, en dos pacientes se predijeron cambios importantes en aminoácidos de la región V3 del gen env (Hís->Arg y Glu->Lis en las posícíones 10 y 22, respectivamente). Al inocular ratones hu-PBL-SICD con los aislados de algunos pacientes, observamos depleción de linfocitos $\mathrm{T} \mathrm{CD}^{+}$en todos los casos, lo cual sugiere que aún con las mutaciones observadas en el gen env y en el LTR, los virus son patogénicos e infecciosos in vivo. En cuanto a la respuesta inmune, hemos observado que los sueros de esos pacientes neutralizan la cepa prototipo HIV1 III . Por último, se midieron los marcadores de activación HLA-DR y CD38 en tres pacientes infectados más de 13 años, mostrándose co-expresión en dos pacientes y mediana expresión en el último.

IDENTIFICACION DE NUEVOS PORTADORES DEL VIRUS LINFOTROPICO DE CELULAS T HUMANAS

\section{Revista Biomédica}




\section{Congreso Nacional de Bioquímica y Biología Molecular de Virus.}

TIPO II EN LA ETNIA MAYA DE YUCATAN. Góngora-Biachi RA, González-Martínez P, Lara-Perera D, Moguel-Rodríguez W, Pavía-Ruz N, Castro-Sansores L, Vera-Gamboa L, Coronado-Bastarrachea R. Centro de Investigaciones Regionales "Dr. Hideyo Noguchi" UADY, Secretaria de Salud del Edo. de Yucatán, Mérida, Yucatán, México.

Los virus linfotrópicos de células T humanas (HTLV) tipo I y II, son retrovirus biológicamente relacionados. El HTLV-I se asocia a la Leucemia del Adulto de Células T y a la Mielopatía Espástica. El HTLV-II no ha sido asociado consistentemente con alguna enfermedad. El HTLV-II ha sido identificado en etnias de amerindios ya hemos identificado una familia perteneciente a la etnia maya con infección por HTLV-II. En este trabajo identificamos nuevos portadores de HTLV-II en esta etnia. Se estudiaron a sujetos de etnia maya que residían en comunidades del oriente de la Península de Yucatán. Se realizó una encuesta epidemiológica y se determinó en suero anticuerpos contra HTLV por ensayo inmunoenzimático (Cambridge Biotech, Rockville, MD). Los resultados positivos se confirmaron y tipificaron por inmunoelectrotransferencia utilizando un ensayo que incorpora proteínas transmembranas recombinantes específicas para HTLV-I (rgp46 y HTLV-II $\left(\mathrm{rgp}_{4} 6^{\mathrm{II}}\right)$ (Diagnostic Biotechnology, Singapore). Se estudiaron a 213 personas (11 mujeres y 202 hombres, promedio de edad de 30.8 años, [17-77 años]). En dos sujetos la detección de anticuerpos fue positiva (prevalencia de $0.9 \%$ I.C. al 95\% 0.5-1.3). Un hombre de 18 años residente de Tekom, sin inicio de vida sexual activa y sin antecedentes de transfusión, uso de jeringas no desechables y tatuajes. El otro caso es un hombre de 52 años residente de la comunidad de Xalau, casado, con una sola pareja durante 32 años, sin prácticas sexuales extraconyugales y sin antecedentes de transfusión, uso de jeringas no desechables y tatuajes. Nuestros resultados confirman la presencia del HTLV-II en la etnia maya y su baja prevalencia. Las rutas de infección en estos dos casos no pudieron identificarse.

RELACION ENTRE MARCADORES VIROLOGICOS Y MANIFESTACIONES CLINICAS EN PACIENTES CON INFECCION POR VIH-1. Valadez-González N. Góngora-Biachi RA, Lara-Perera D, Castro-Sansores C, Puerto-Manzano FI, Martínez-Ruiz ML, Ancona-Canto CL. Centro de Investigaciones Regionales "Dr. Hideyo Noguchi", Universidad Autónoma de Yucatán. Mérida, Yucatán, México.

La progresión clínica de la infección del VIH se ha asociado a las características biológicas del VIH y depleción de linfocitos CD4. El objetivo de este trabajo fue conocer la relación de estas variables con el cuadro clínico. De oct/ 1996 a ene/1999 se estudiaron a 40 pacientes (22 casos de Sida y 18 casos de clase clínica A y B) sin terapia antiretroviral previa. Se administró AZT (500 mg/día) + ddI(400 mg/día). Se realizó un periodo observacional de un año con evaluaciones clínicas mensuales y trimestralmente se determinó la carga viral (Chiron Diagnostics), fenotipificación viral (IS o no IS) y genotipificación para búsqueda de mutaciones del codón 184 y 74 y del codón 215, Ag-p24 y cuenta de linfocitos CD4. Dos pacientes del grupo A/ B fueron excluidos; 14/22 (64\%) pacientes con Sida y 2/16 (13\%) del grupo A/B tuvieron progresión de enfermedad (PE) $(\mathrm{p}=0.004), 10 / 14(71 \%)$ pacientes con Sida y PE y $0 / 8$ de los no progresores (NPE) de este grupo tenían desde la evaluación inicial un fenotipo IS $(\mathrm{p}=0.001$, OR 3 (1.35-6.7)). Todos los PE (16/16, 100\%) desarrollaron fenotipo IS y solamente $4 / 22(18 \%)$ NPE tuvieron IS $(p=0.0003)$. Las frecuencias de las mutaciones estudiadas entre los pacientes PE y NPE, de ambos grupos, no fue, estadísticamente diferente. En los pacientes NPE de ambos grupos las cargas virales se mantuvieron menores a 10,000 copias $/ \mathrm{mL}$ y la condición contraria ocurrió en los PE. Los CD4 disminuyeron en los PE y se mantuvieron estables o con incrementos menores del 30\% en los NPE. No se estableció relación entre el curso clínico de la enfermedad y el Ag-p24. El fenotipo IS, la carga viral y el conteo CD4 fueron predictores de $\mathrm{PE}$, mientras que las mutaciones virales no lo fueron. El esquema terapéutico probado es útil, al menos por un año, en alrededor del $87 \%$ de los pacientes clases clínicas A2/B2 y en el 36\% de los pacientes con Sida.

DIAGNOSTICO COMPARATIVO DE LA INFECCION POR VIRUS SINCICIAL RESPIRATORIO CON INMUNOFLUORESCENCIA DIRECTA Y LA REACCION EN CADENA DE LA POLIMERASA EN NIÑOS HOSPITALIZADOS POR NEUMONIA. 'BustamanteCalvillo ME, ${ }^{1}$ Velázquez FR, ${ }^{1}$ Peña-Arguelles AL, ${ }^{2}$ Reyes-Morales H., ${ }^{2}$ Guiscafre-Gallardo $\mathrm{H}$, ${ }^{1}$ Torres $\mathrm{J},{ }^{1} \mathrm{Mu}$ ñoz Hernández O. ${ }^{1}$ Unidad de Investigación Médica en Enfermedades Infecciosas y Parasitarias, Hospital de Pediatría, ${ }^{2}$ Unidad de Investigación en Epidemiología y Servicios de Salud. Edificio Regional, C.M.N. Siglo XXIIMSS, México, D.F., México.

Introducción: El virus sincícial respiratorio (VSR) es causa de neumonía o bronquiolitis en niños $<2$ años de edad. Para su detección se utilizan el método de cultivo de tejido y/o ínmunofluorescencia directa (IFA), como "estándar de oro".

Objetivo: Comparar la concordancia que tienen la IFA y la reacción en cadena de la polimerasa (PCR), para la detec-

Vol. 11/No. 2/Abril-Junio, 2000 


\section{A García-Carrancá, RM del Angel, R Rivera-Torres.}

ción de la infección por VSR en muestras nasofaríngeas de niños $<5$ años hospitalizados por neumonía.

Métodos: Se probaron 3 tomas del muestra nasofaríngea: lavado, hisopo sencillo y doble; comparando el número de células y la concentración de ARN. Se estudiaron 25 niños con neumonía y 5 sin neumonía, ingresados al Sistemas del Sector Salud, en el estado de Hidalgo. Las muestras se dividieron para realizar IFA y PCR. Para la IFA, las células se fijaron en laminilla, añadiéndose anticuerpos específicos para VSR. Se consideró una muestra positiva, cuando se observaron inclusiones citoplásmicas fluorescentes. Para la PCR, se efectuó extracción del ARN de las células nasofaríngeas, realizando transcripción reversa para obtener el ADNC que se amplificó por la PCR, usando, oligonucleótidos para la glicoproteína F, con un segundo PCR anidado. Se realizó electroforesis en gel de agarosa, observándose en los casos positivos las bandas de 390 pb y 207 pb, respectivamente.

Resultados: Al comparar el número de células nasofaríngeas de acuerdo al método de colección de la muestra, se observó que el lavado y el hisopo sencillo presentaron un promedio 3 células por 10 campos, con una DO de ARN de 0.05, y con dos hisopos un promedio de 18 células por 10 campos con una DO de 0 . 1 . Del total de casos: 8/30 (27\%) fueron positivos a VSR tanto por IFA y PCR, con una concordancia perfecta (kappa=1; $\mathrm{P}<0.0001), 8 / 25(32 \%)$ fueron niños con neumonía, 0/5 (0\%) sin neumonía.

Conclusiones: Para la detección de VSR, se sugiere la toma de muestra con doble hisopo nasofaríngeo, para obtener un promedio mínimo de 10 células por campo, que por medio de la extracción del ARN, se obtenga una DO 0.1 para realizar la IFA y PCR. La concordancia es alta en la detección de infección por VSR, entre la IFA y la PCR en niños $<5$ años de edad hospitalizados por neumonía.

PRESENTACIÓN DE ANTÍGENO VIRAL POR MOLÉCULAS DEL COMPLEJO PRINCIPAL DE HISTOCOMPATIBILIDAD EN MACRÓFAGOS PERSISTENTEMENTE INFECTADOS CON EL VIRUS SINCITIAL RESPIRATORIO. Guerrero-Plata A. OrtizNavarrete V. y Gómez-García B. Depto. de Microbiología y Prasitología, Facultad de Medicina UNAM. Depto. de Biomedicina Molecular, CINVESTAV, México, D.F., México.

El virus Sincitial Respiratorio (RSV) se considera el principal agente etiológico de bronquiolitis y neumonías severas en niños menores de un año. Los macrófagos alveolares son considerados como la principal línea de defensa contra el virus. La fisiopatología del daño a vías respiratorias y la híper-reactividad está asociada a la presencia de células inflamatorias reclutadas por citocinas
(IL-5) liberadas por linfocitos $\mathrm{T} \mathrm{CD} 8^{+}$estimulados por células infectadas con RSV. Por lo tanto, la presentación de antígeno del RSV por moléculas clase I del MHC en células infectadas puede ser un factor relevante dentro de la patogénesis de la enfermedad. En el presente trabajo se estudia el efecto de la persistencia del RSV sobre la capacidad de los macrófagos de presentar antígeno a células CTL RSV específicas. Utilizando un cultivo in vitro de macrófagos persistentemente infectados con RSV (MФP), se determinó por citometría de flujo la expresión de las moléculas MHC I en estas células. Se hicieron ensayos de citotoxicidad utilizando células CTL RSV específicas como electoras y los M como blanco. Los resultados demuestran que la persistencia del RSV en macrófagos origina un incremento en la expresión de superficie de las moléculas MHC I. Además induce una constante presentación de antígeno de RSV a células CTL RSV específicas. Lo anterior podría estar relacionado con los procesos de inflamación presentes en pacientes infectados con este virus que presentan bronquitis crónica o que desarrollan síntomas asmáticos.

FRECUENCIA DEL VIRUS SINCICIAL RESPIRATORIO DETECTADO POR EL METODO DE LA REACCION EN CADENA DE LA POLIMERASA (PCR) EN NIÑOS MENORES DE DOS AÑOS DE EDAD QUE FALLECIERON CON NEUMONIA. ${ }^{1}$ BustamanteCalvillo ME, ${ }^{1}$ Velázquez FR, ${ }^{1}$ Peña-Arguelles AL, ${ }^{2} \mathrm{Ca}$ brera Muñoz ML, ${ }^{1}$ Gómez-Delgado A, ${ }^{1}$ Torres $J$, ${ }^{1}$ Muñoz Hernández O. 'Unidad de Investigación Médica en Enfermedades Infecciosas y Parasitarias, Hospital de Pediatría. ${ }^{2}$ Servicio de Anatomía Patológica Hospital de Especialidades, C.M.N. Siglo XXI-IMSS, México, D.F., México.

Introducción: El virus sincicial respiratorio (VSR) es causa de infecciones graves de las vías respiratorias, ocasiona neumonía o bronquiolitis en niños $<2$ años de edad. En nuestro país se desconoce si VSR es causa importante de muerte en niños con neumonía.

Objetivo: Determinar la frecuencia del VSR en muestras de tejido pulmonar de niños $<2$ años de edad que murieron con neumonía, mediante la técnica de la PCR usando oligonucléotidos que amplifican la glicoproteína F.

Métodos: Se estudiaron 98 muestras de pulmón incluidas en parafina de niños $<2$ años de edad, que fallecieron con diagnóstico anatomopatológico de neumonía, en el Hospital de Pediatría del C.M.N., S-XXI, durante el período de 1989 a 1997. Cortes de $10 \mu$ de pulmón se desparafinaron con xileno, se extrajo el ARN total para efectuar transcripción reversa y obtener ADNc que se amplificó por PCR usando oligonucleótidos para la glicoproteína F, con un segundo

\section{Revista Biomédica}




\section{Congreso Nacional de Bioquímica y Biología Molecular de Virus.}

PCR anidado. En las muestras que resultaron negativas a VSR por PCR se demostró la ausencia de inhibidores inespecíficos, empleando un control interno de VSR. Además, se comprobó la integridad del ADNc por PCR, usando oligonucleótidos específicos para el gen FMR-1 del cromosoma X humano.

Resultados: De las 98 muestras de pulmón de niños que fallecieron con neumonía, 29/98 (30\%) resultaron positivas a VSR por PCR. De estas, 8/13 (62\%) fueron de niños con una patrón histopatológico de neumonía viral y 21/85 (25\%) fueron de niños con un patrón histopatológico de neumonía bacteriana $(\mathrm{P}=0.018)$. La infección por VSR no mostró diferencia significativa en relación con la edad y por temporada del año.

Conclusiones: La infección por VSR fue común en niños < 2 años de edad que fallecieron con neumonía, siendo más frecuente en los casos con patrón anatomopatológico de neumonía viral, pero también se identificó como infección mixta en aquellos casos con patrón anatomopatológico de neumonía bacteriana.

ESTUDIO DE LA PROTEINA DE LA CAPSIDE DEL VIRUS DE LA MANCHA ANULAR DE LA PAPAYA EN MEXICO. ${ }^{1}$ Noa-Carrazana JC, ${ }^{1}$ Ruiz-Castro B, ${ }^{1}$ Tovar-Cortés $\mathbf{R}$, ${ }^{2}$ Becerra EN, ${ }^{1}$ Silva-Rosales $L$. ${ }^{1}$ CINVESTAV-IPN Irapuato. ${ }^{2}$ Campo Exp. Cotaxtla. INIFAP, Guanajuato, México.

El papayo es un cultivo de importancia económica en México ya que ocupa el segundo lugar entre los países productores de papaya. El Virus de la Mancha Anular de la Papaya (VMAP) pertenece al grupo de los Potyvirus y causa una de las enfermedades más destructivas en este cultivo. En México, su presencia ha causado pérdidas del 50 al $90 \%$ en las cosechas. Este virus se encuentra ampliamente distribuido en todas las zonas papayeras del país: Veracruz, Oaxaca, Tabasco, Colima, Nayarit, Jalisco y Guerrero. El objetivo general del presente trabajo es la caracterización molecular de aislamientos mexicanos de este virus. Para ello se implementó su detecci6n y clonación parcial a partir de las reacciones de transcripción inversa y de polimerizacíón en cadena (RT-PCR) con oligonucleótidos específicos para el gen de la proteína de la cubierta (CP). Se estudió la variabilidad de esta región por medio de análisis comparativos de las secuencias nucleotídicas y sus predicciones aminoacídicas en 17 secuencias del gen de la CP de aislamientos de 8 estados productores de papaya. Los análisis de identidad entre aislamientos mexicanos y otros reportados en el banco de genes muestran una estrecha relación filogenética entre nuestros aislamientos y los de Estados Unidos y Australia; en contraste, hay un distanciamiento con los de origen asiático. Estudios de la región amino terminal de la $\mathrm{CP}$ muestran diferencias en rearreglos del dipéptido ácido glútamico, lisina (EK), en los aislamientos. Se discutirá la posible función e implicación evolutiva de éstos repetidos.

DETECCION Y CARACTERIZACION MOLECULAR DEL VIRUS DEL MOSAICO COMUN DEL FRIJOL (BCMV) EN EL ESTADO DE GUANAJUATO. Flores-Estevez N ${ }^{1}$, Acosta GJ ${ }^{2}$, Sílva-Rosales L ${ }^{1}$. ${ }^{1}$ Depto. Ing. Genética, CINVESTAV-IPN. Irapuato Gto. ${ }^{2}$ INIFAP Campo experimental Valle de México.

El virus del mosaico común del frijol (BCMV) es un patógeno ampliamente distribuido en nuestro país y causa pérdidas de un $30 \%$ aproximadamente. El diagnóstico de este virus presenta complicaciones debido a su estrecha relación y similitud de síntomas con el virus del mosaico necrótico común del frijol (BCMNV). Ambos virus están incluidos en el género Potyvirus. En nuestro laboratorio implementamos una metodología basada en la técnica de transcripcion inversa y reacción en cadena de la polimerasa (RT-PCR), utilizando tres iniciadores diferenciales en la proteína de la cápside: uno dirigido a la región conservada y los otros dos, a la región variable para cada uno de los virus. Esta técnica ha permitido diagnosticar al BCMV y diferenciarlo eficientemente del BCMNV en plantas con síntomas de mosaico o necrosis. Con esta técnica se analizaron muestras de frijol en seis localidades del estado de Guanajuato: Abasolo, lrapuato, Romita, Santa Rosa de Gavia y Las Masas, Cuerámaro. En todas ellas detectamos únicamente al BCMV como causante del mosaico. Los análisis de comparación de las secuencias clonadas con secuencias reportadas para ambas especies virales en el banco de genes, corroboraron que efectivamente se trataba de aislamientos de BMCV con porcentajes de similitud de un $57 \%$ hasta $92 \%$. Se discutirá la posible razón por la cual únicamente se ha detectado el BMCV en Guanajuato y no el BCMNV.

TRANSACTIVACIÓN HETERÓLOGA DEL GEN DE LA PROTEÍNA DE LA CÁPSIDE DE GEMINIVIRUS. Vega Arreguín JC, Monsalve Fonnegra ZI, Vaca Vaca JC, Argüello Astorga GR, Rivera Bustamante RF. CINVESTAV-IPN. U. Irapuato, Guanajuato, México.

Los Geminivirus son una familia de virus de plantas que poseen genoma circular de DNA de cadena sencilla, con uno o dos componentes genómicos según el virus y se replican en el núcleo de la planta huésped mediante un mecanismo de círculo rodante. Los Geminivirus se clasifican en tres géneros de acuerdo a su rango de huéspedes, a su 


\section{A García-Carrancá, RM del Angel, R Rivera-Torres.}

insecto vector y a su organización genómica. Miembros del género Begomovirus como el PHV (pepper huasteco virus), TPV (Texas pepper virus) y TToMoV (taíno tomato motie virus), entre otros, son del tipo bipartita, en los cuales el componente A codifica para la proteína de la cápside y todas las proteínas virales necesarias para la replicacíón y la expresión génica, mientras que en el componente B, están codificadas las proteínas del movimiento del virus en la planta. La proteína transactivadora (TRAP) codificada por el virus, regula la expresión de los genes de la cápside (CP) y de la proteína de movimiento (MP) (genes tardíos), a nivel de la transcripción. Este proceso de regulación transcripcional no es muy conocido hasta el momento, aunque se han identificado ya secuencias en los promotores de dichos genes tardíos de algunos geminívirus que podrían actuar como blancos funcionales de TRAP. Tales secuencias denominadas CLEs (Conservated Late Elements), no se han encontrado en todos los geminivirus y en aquellos que las presentan su organización es variable. Así, PHV presenta CLEs en ambas orientaciones en el promotor del gen de la $\mathrm{CP}$, mientras que en TPV se encuentran sólo en sentido inverso y TToMoV no cuenta con CLEs típicos. Se realizaron ensayos de expresión transitoria, utilizando el gen reportero GUS fusionado al promotor del gen de la proteína de la cápside de TToMoV y TPV, con el fin de observar si la proteína TRAP de ambos virus transactiva su propia CP aún en ausencia de secuencias CLE. De la misma manera se realizaron ensayos de transactivación heteróloga entre PHV, TPV y TToMoV para evaluar funcional y comparativamente los promotores de la CP de cada uno de estos geminivirus con respecto a la transactivación por TrAP.

ESTUDIO DE ELEMENTOS CIS REGULADORES INVOLUCRADOS EN LA TRANSACTIVACIÓN DE GENES TARDIOS DE GEMINIVIRUS. MonsalveFonnegra ZI, Ruíz-Medrano R, Argüello-Astorga G, Rivera-Bustamante RF. Centro de Investigación y Estudios Avanzados del I.P.N., U.I., Apartado Postal 629, Irapuato, Gto., México.

La familia Geminiviridae se compone de virus fitopatógenos que tienen DNA como material genético y su ciclo replicativo y expresión génica se llevan a cabo en el núcleo de las células infectadas. En estos virus se han reportado mecanismos de regulación génica tales como la transactivación y el silenciamiento. La transactivación es llevada a cabo por la proteína TrAP, la cual estimula la expresión de los genes tardíos CP (proteína de la cápside) y BVl (proteína de movimiento núcleo-cítopiasma). En estudios previos se identificó una secuencia conservada en muchos geminivirus que fue denominada CLE (Conserved Late Element) la cual se postuló como el sitio blanco de
TrAP y cuya secuencia consenso es GTGGTCCC. Las comparaciones de secuencias revelaron que los CLEs presentan diferencias tanto en el número como en la orientación dentro de los promotores virales. Dada la importancia de los CLES, se consideró importante delimitar los nucleótidos que son críticos para la función y determinar la importancia de su número y orientación. De igual forma se evaluó si los CLEs pueden conferir la capacidad de transactivación a promotores heterólogos de diferentes geminivirus. Los resultados obtenidos nos permiten establecer que los nucleótidos TGGTCC del consenso son indispensables en el proceso de transactivación, y que la orientación en que se encuentran es una variable de importancia, al menos cuando son evaluados en un promotor heterólogo. Adicionalmente se demostró que TrAPs de diferentes virus pueden transactivar promotores heterólogos que contienen CLES, lo cual sugiere que la transactivación de los genes tardíos de gemínivirus involucro un mecanismo general. Esta característica puede tener una importante aplicación biotecnológica en el diseño de estrategias antivirales.

TRANS-COMPLEMENTACIÓN ASIMÉTRICA EN MOVIMIENTO ENTRE EL VIRUS HUASTECO DEL CHILE Y EL VIRUS TEXANO DEL CHILE EN UNA INFECCIÓN MIXTA TRIPARTITA. Méndez-Lozano J, Fauquet CM, Rivera-Bustamante R.F. Departamento de Ingeniería Genética, CINVESTAV IPN, U. Irapuato, México. ILTAB, Danforth Plant Scíence Center, St. Louis, MO USA.

Las infecciones mixtas por geminivirus son muy comunes en regiones tropicales. En México, el virus huasteco del chile (PHV) y el virus Texano del chile (TPV) ambos bipartitas (componente A y B), se presentan como una mezcla predominante. Se ha reportado que este tipo de infecciones puede ser una fuente de variabilidad a través de la pseudrorecombinación y/o recombinación entre genomas participantes. Además, los virus pueden interaccionar complementándose en ciertas condiciones. En un primer ensayo para determinar el tipo de interacciones que se pueden presentar, se observó que PHV y TPV no pueden formar pseudorecombinantes (DNA A de PHV fue incapaz de trans-replicar el DNA B de TPV y viceversa). Por otro lado, se analizó las interacciones a nivel de movimiento. Para estos ensayos se utilizaron virus quiméricos en los cuales la proteína de la cápside fue sustituida por la proteína fluorescente verde (GFP) usándolo como gen marcador para seguir el movimiento del virus. Plantas de Nícotíana benthamiana y Nicotíana tabacum var. xanthi fueron coinoculadas con mezclas tripartitas (PHV DNA A+B y TPV DNA A-GFP o TPV DNA A+B y PHV DNA A-GFP). El 


\section{Congreso Nacional de Bioquímica y Biología Molecular de Virus.}

análisis de la replicacíón viral y expresión de la GFP en hojas apicales mostró que PHV puede complementar (facilitar o promover) el movimiento sistémico de TPV DNA A-GFP, pero TPV no complementa a PHV DNA A-GFP. Además, esta complementación asimétrica en movimiento no es dependiente del hospedero. Estos resultados sugieren que interacciones entre geminivirus en mezclas de infección puedan facilitar los mecanismos de evolución viral.

LAS VARIANTES ASIÁTICO-AMERÍCANAS DEL VIRUS DEL PAPILOMA HUMANO TIPO 16, TIENEN GRAN NUMERO DE MUTACIONES EN EL GEN E2 Y SE ENCUENTRAN MUY AMPLIFICADAS EN CARCINOMAS CERVICALES. Casas $\mathbf{L}^{\mathbf{1}}$, Galván $\mathbf{S}^{2}$, Ordóñez $R^{2}$, López $\mathrm{N}^{1,3}$ Guido $\mathrm{M}^{2}$, Berumen $\mathrm{J}^{\mathrm{l}}$, ${ }^{4} \mathrm{Lab}$. Multidis. de Invest., Esc. Militar de Grads, de Sanidad, UDEFA; ${ }^{2}$ Inst. de Invest. Biomédicas, UNAM; ${ }^{3}$ Departamento de Biología Celular, CINVESTAV, IPN; Centro de Invest. en Ciencia Aplicada y Tecnol. Avanzada, IPN. México, D.F.

La proteína E2 del virus del papiloma humano (HPV) participa en la regulación de la expresión genética y la replicación viral. La ruptura del gen E2 durante la integración viral ha sido propuesta como un mecanismo de progresión tumoral, ya que permite la expresión de los oncogenes E6/E7. Sin embargo, en algunas poblaciones con carcinomas positivos para HPV16, es frecuente encontrar la retención de los genes El/E2 y un alto nivel de amplificación viral.

En este trabajo, se investigó si la retención de E1/ E2 y la amplificación viral, se asocian con variantes de E2 del HPV16 en carcinomas cervicales. En 123 carcinomas cervicales se exploró por Southern blot (SB) la presencia de HPV16, la integridad de El/E2 y la amplificación viral. Las variantes se identificaron por SB y secuenciación de las regiones E6, L1/MY y E2.

De 46 tumores positivos para HPV16, 34 retuvieron la región El/E2 y 14 mostraron un patrón de restricción variante debido a mutaciones en E2. Estos últimos, fueron positivos para variantes AsiáticoAmericanas (AA) y de 11 sub-clasificados, 6 fueron AA-a y 5 fueron AA-c. Dos tumores negativos para E1/E2, también contienen la variante AA-c, mientras que el resto contienen sólo variantes Europeas. El gen E2 de las variantes AA presentó 24 mutaciones, 19 de ellas fueron idénticas en ambas subclases. Las 24 mutaciones se distribuyeron a lo largo de todo el gen y 19 de ellas resultan en 18 cambios de aminoácido. Las variantes AA se asociaron con carcinomas positivos para E1/E2, con más de 50 copias/célula ( $\mathrm{p}=0.035$ ). La asociación de las variantes de Asiático-Americanas con la retención de E1/E2, sugiere que la variación de E2 puede ser un mecanismo alternativo de desregulación de la expresión de los oncogenes virales.

DNA DEL VIRUS DEL PAPILOMA HUMANO EN PLASMA DE PACIENTES CON CARCINOMA CERVICOUTERINO: UN POTENCIAL MARCADOR DE ENFERMEDAD RESIDUAL MÍNIMA. Carrillo AL, Wójcik EJ, Lizano M, Fresnedo L, Sánchez A, Trejo C, Rojas C, Dueñas A. División de Investigación Básica. Instituto Nacional de Cancerología, SS, México, D.F., México.

El carcinoma cervicouterino es una neoplasia muy común en nuestro país, y la principal causa de muerte por cáncer en mujeres mexicanas. Se sabe que el Virus del Papiloma Humano juega un papel muy importante en el desarrollo del CACU, ya que se ha encontrado una asociación de cerca del $95 \%$ entre la infección por dicho virus y el cáncer.

Desde hace varios años se ha demostrado que el DNA se encuentra circulando en el suero de pacientes con cáncer, guardando una relación directa la cantidad de DNA circulante con la carga tumoral. Los niveles de DNA en suero disminuyen en el $99 \%$ de los pacientes con mejoría clínica o reducción del tamaño tumoral, y aumentan en caso de progresión de la enfermedad.

En este trabajo analizamos mediante PCR la presencia de secuencias de VPH tanto en el plasma de 70 pacientes con CACU cuyos tumores primarios expresaron VPH, como de 24 pacientes con infección cervical por VPH pero sin cáncer, además de 10 mujeres sanas. Comprobamos que el DNA del VPH se encuentra circulando en el plasma del $70 \%$ de las pacientes con cáncer, pero está ausente en las pacientes sin cáncer, con infección activa y en los casos controles. Varias de las pacientes con cáncer que han sido tratadas se han estado siguiendo con análisis de plasma periódicos, con lo que pudimos demostrar la existencia de una relación entre la recurrencia de la enfermedad y la presencia de DNA viral en plasma. Lo anterior sugiere que la detección de secuencias de DNA de VPH en el plasma de las pacientes con CACU es indicativa de presencia de tumor, lo que constituye un marcador tumoral muy sensible y $100 \%$ específico.

Así, la determinación de DNA viral en plasma de las pacientes con cáncer de cérvix podría tener aplicaciones terapéuticas en el sentido de que su persistencia, pese a una respuesta clínica completa podría interpretarse como presencia de enfermedad residual mínima, ya que la única fuente del DNA viral provendría de células tumorales. En este caso, las terapias adyuvantes o complementarias serían de mayor utilidad, existiendo criterios para la selección de pacientes en riesgo de recurrencia clínica. 
A García-Carrancá, RM del Angel, R Rivera-Torres.

\begin{abstract}
ASOCIACIÓN ENTRE LAS VARIANTES DEL VIRUS DEL PAPILOMA HUMANO 16, LA REGULACIÓN DE LA EXPRESIÓN DE LOS ONCOGENES VIRALES POR E2 Y LA EDAD DE LAS PACIENTES CON CANCER CERVICAL. Ordoñez RM ${ }^{1}$, López $\mathbf{N}^{1,2}$, Galván $S^{1}$, Casas $L^{1}$, García-Carrancá $A^{3,6}$, GonzálezLira $\mathrm{G}^{4}$, Berúmen $\mathrm{J}^{1,5}$. ${ }^{1}$ Lab.Multidisciplinario de Investigación de la Escuela Militar de Graduados de Sanidad, UDEFA;.'Depto. de Biología Celular, CINVESTAV; ${ }^{3}$ Inst. de Invest. Biomédicas, UNAM. ${ }^{4}$ Hospital de Gineco-Obstetricia No. 4,IMSS. ${ }^{5}$ CICATA, IPN. ${ }^{6}$ Inst. Nacional de Cancerología, SS, México, D.F., México.
\end{abstract}

El Virus del Papiloma Humano 16 (HPV16) es detectado en cerca del $50 \%$ de los carcinomas cervicales. Las variantes de HPV16 se asocian con neopiasias de alto grado o invasivas y están distribuidas por regiones geográficas. La alta incidencia de cáncer cervical en México $(50 / 100,000)$ puede ser asociada con la alta prevalencia de variantes oncogénicas. Nosotros exploramos la prevalencia de las variantes de HPV16, en 169 pacientes mexicanas con cáncer cervical, y su asociación con datos clínicos y con la regulación de la transcripción de los oncogenes E6/ E7 por la proteína E2. El tipo de HPV fue detectado por PCR universal (MY/L1) y tipificados por secuenciación. Las clases y subclases de las variantes de HPV16 fueron identificadas por secuenciación de las regiones MY/L1 y E6. La actividad de E2 de las variantes fue explorada en células $\mathrm{C} 33 \mathrm{~A}$ y $\mathrm{HaCaT}$, que contienen el gen reportero $\beta$ galactosidasa regulado por la Región Larga de Control (LCR) del HPV16, y en células HeLa y Siha que expresan constitutivamente los oncogenes E6/E7.

De los 87 carcinomas HPV16 positivos (51.5\%), sólo 77 fueron subtipificados. Las variantes Europeas (E) y Asiatico-Américanas (AA) fueron las más frecuentes (54.6\% y $44.2 \%$, respectivamente). Las variantes AA predominaron en pacientes de 35 años $(57.2 \%, 8 / 14)$, mientras que las $\mathrm{E}$ fueron más frecuentes en pacientes mayores de 35 años (28.3\%, 41/145; p=0.009, Fisher). La edad promedio de las pacientes AA positivas $(47.3 \pm 2.24)$ fue 6.3 años menor a la edad media de las pacientes positivas para las E (534.6 $\pm 1.74, \mathrm{p}=0.026, \mathrm{t}$ de student); esta diferencia fue dada principalmente por la subclase AA-c (media $=43.2 \pm 2.78$, $\mathrm{p}=0.0035$. $\mathrm{t}$ de student). Los genes E2 de las variantes AA no reprimieron (AA-c) o reprimieron con menor fuerza (AA-a) el LCR del HPV16 comparado con el E2 Europeo.

La asociación de las variantes AA con mujeres jóvenes y la disminuida represión de E2 sugiere que estas variantes son altamente oncogénicas. La alta frecuencia de las variantes AA podría contribuir a la alta incidencia de este cáncer en México.

\section{Revista Biomédica}

E5 DE HPV16 Y EL RECEPTOR PARA EGF REGULAN LOS NIVELES DE LA PROTEÍNA p27 ${ }^{\text {Kip1. }}$ Pedroza SA ${ }^{1}$, Valdovinos $\mathbf{T H}^{1}$, Maldonado $\mathbf{M}^{1}$, Collado $\mathrm{M}^{2}$, Esquivel $\mathrm{F}^{3}$, Lam $\mathrm{E}^{2}$, Gutiérrez XL ${ }^{1}$. ${ }^{1}$ CISEHINSP, Cuernavaca, Mor., México; ${ }^{2} L u d w i n g$ Institute for Cancer Research, Londres, Inglaterra; ${ }^{3}$ Fac. de Medicina, U. del Edo. de Morelos, México.

Los papilomavirus humanos (HPV) son el principal agente etiológico asociado al cáncer cérvico uterino, siendo lo tipos 16 y 18 los más frecuentes. E6 y E7 de HPV16 inmortalizan queratinocitos humanos y requieren de ras y fos para transformar células primarias, además de interactuar con proteínas de ciclo celular, como p53, pRb, $\mathrm{p} 2 \mathrm{l}^{\text {Waf1 }}$, ciclina A, ciclina $\mathrm{E}$ y Cdk2. E5 es otro oncogén de HPV16, cuyo poder transformante se asocia a EGF y su receptor (EGF-R), incrementando su vida media y disminuyendo la expresión del inhibidor p $21^{\text {waf1 }}$, favoreciendo la progresión del ciclo celular en condiciones de arresto, por un mecanismo aún desconocido. p2 $7^{\text {Kipl es }}$ otro inhibidor interesante que causa arresto celular en G1 mediado por inhibición por contacto o privación de factores de crecimiento y debe ser degradado por ubiquitinación para proseguir el ciclo normal. En esta investigación se trató de establecer si E5 actúa sobre p27 y si ello dependía de EGF. Se utilizaron células 3T3, RFC (3T3 que sobreexpresan el EGF-R humano), RFC transfectadas establemente con E5, y dos sistemas inducibles de E5, uno por IPTG (en células murinas) y otro con dexametasona (en células humanas). Los niveles de p21 ${ }^{\text {Waf1 }}, \mathrm{p} 27^{\text {Kip1 }}$, EGF-R y EGF-R activado (anti-fosfotirosina) se determinaron por Western blot. Los resultados mostraron que los niveles de $\mathrm{p} 27^{\mathrm{Kip} 1}$ fueron reducidos hasta en un $90 \%$ en células que expresan E5, tanto en el sistema constitutivo como en el inducible, después de $16 \mathrm{~h}$ de estimulación con EGF. Por Northern blot identificamos que esta regulación no es a nivel transcripcional. Además el receptor para EGF se mantuvo activo por más de $16 \mathrm{~h}$, en comparación con las células que no expresaban E5. En condiciones normales, las células incrementan los niveles de $\mathrm{p} 27^{\mathrm{Kip} 1}$ a elevadas confluencias. Sin embargo, células que expresan E5 requieren de EGF para abatir los niveles de p27 $7^{\text {Kip1 }}$ en alta confluencia. Estos resultados sugieren que E5 junto con EGF y su receptor favorecen la degradación de p2 $2{ }^{\text {Kip1 }}$ y éste pudiera ser un mecanismo por el cual E5 lleva a cabo su actividad oncogénica.

CARACTERIZACIÓN DE LOS FACTORES QUE REGULAN EL PROCESAMIENTO ALTERNATIVO DE E6 Y E7 EN PVH-16. Martínez-Salazar M, VillegasSepúlveda N. Depto. de Biomedicina Mol., CINVESTAVIPN, México, D.F., México. 


\section{Congreso Nacional de Bioquímica y Biología Molecular de Virus.}

Las infecciones por PVH son causa importante de una gran morbilidad y mortalidad en todo el mundo, dichos virus se asocian etiológicamente con el desarrollo de cáncer cervicouterino (CACU) pues se han detectado tipos específicos (PVH16 y 18 principalmente) en por lo menos $90 \%$ de estos carcinomas y en más del $50 \%$ de otros carcinomas anogenitales. En nuestro país el CACU ocupa el primer lugar como causa de muerte en la población femenina adulta. El mecanismo de splicing alternativo (MSA) hace posible la expresión de un número relativamente grande de proteínas a partir de genomas muy pequeños y contribuye a regular tanto en forma ontogénica como tejido-específico el patrón de expresión de un gene. Las proteínas de Papilomavirus humanos son codificadas por mRNAs policistrónicos tanto en tumores como en líneas celulares los cuales son procesados postranscripcionalmente por MSA. La selección y reunión de exones en MSA se lleva a cabo con una precisión asombrosa en un proceso en el que deben participar varios factores trans-acting. En este trabajo pretendemos caracterizar algunos de los factores trans que participan en el MSA de E6 y E7 en PVH-16 con el fin de entender mejor los mecanismos mediante los cuales PVH-16 puede generar una gran diversidad de mRNAs; para alcanzar este objetivo llevamos a cabo ensayos de unión RNA-proteína mediante entrecruzamientos con UV utilizando como sondas mRNAs (E6-E7) transcritos in vitro y proteínas nucleares de células HeLa. Los mRNAs interaccionan con 7 proteínas cuyos PM están entre 35-85 $\mathrm{kDa}$. La interacción de estas proteínas con el mRNA es afectada por la fuerza iónica, $\mathrm{MgCl}_{2}$ y ATP pero unas cuantas proteínas permanecen unidas bajo todas las condiciones experimentales. Estos resultados sugieren que las proteínas unidas específicamente al mRNa de E6-E7 de PVH16 constituyen candidatos potenciales de factores que podrían participar en el splicing alternativo de PVH-16.

\section{ANÁLISIS DE LOS ELEMENTOS REGULADORES QUE INDUCEN LA EXPRESIÓN DE TGF-ß1 POR HPV EN CÁNCER CERVICAL. Peralta-Zaragoza $O^{1}$, Barboza $C^{1}$, Lagunas $A^{2}$, Bahena $\mathbf{M}^{1}$, Gariglio $\mathbf{P}^{2}$, Madrid-Marina $V^{1}$. ${ }^{1}$ Instituto Nacional de Salud Pública, Cuernavaca Morelos, México; ${ }^{2}$ CINVESTAV-IPN, México, D.F., México.}

La infección por HPV es un problema de salud ya que hay una correlación de la presencia del DNA, de HPV y el desarrollo de CACU, En México el CACU es una neoplasia que representa el $30 \%$ de los cánceres en mujeres y de éstos el 90\% son HPV+ Se sabe que E6 y E7 de HPV tienen propiedades oncogénicas y transraguladoras. Nosotros hemos identificado la expresión de citocinas inmunosupresoras en biopsias de CACU con prevalencia de IL-4 IL-10 y TGF $\beta 1$, lo cual sugiere el desarrollo de una inmunosupresión local en pacientes con CACU, TGF- $\beta 1$ es una citocina multifuncional con mecanismos moleculares de regulación complejos., los cuales no son entendidos totalmente durante el desarrollo del CACU. Por tal motivo, en el presente estudio se analizan los mecanismos moleculares por los cuales el HPV puede regular la expresión de TGF- $\beta 1$.

El análisis de la región reguladora de TGF- $\beta 1$ humano sugiere la presencia de elementos reguladores que pueden interactuar con complejos transcripcionales celulares y/o con las oncoproteínas E6 y E7 de HPV, por lo que se amplificó por PCR ta región reguiadora de TGF- $\beta 1$ a partir de DNA de linfocitos de individuos sanos, se clonó en pBluescript y se secuenció. Se generaron diferentes subfragrnentos por digestión enzimática, y se identificó por EMSA y con extractos nucleares de líneas celulares tumorales cervicales, la formación de complejos DNA/ proteína en secuencias reguladoras de interés. Se generaron diferentes construcciones con deleciones del promotor de TGF- $\beta 1$, con las cuales se están realizando los experimentos de cotransfección con los genes E6 y E7 de HPV para identificar las actividades de transactivación sobre el promotor de TGF- $\beta 1$. Los complejos DNA/proteínas y la funcionalidad de los mismos pueden explicar parte de los mecanismos rnoleculares de regulación de TGF- $\beta 1$ durante el desarrollo del CaCU.

PREVALENCIA DE GENOTIPOS DEL VIRUS DE HEPATITIS C EN PACIENTES CON ENFERMEDAD HEPÁTICA. Trejo-Avila $\mathbf{L}^{1,3}$, Martínez $\mathbf{V}^{1,3}$, Trejo $\mathbf{R}^{2}$, Isibasi $A^{2}$, Cabrera $A^{2}$, Patiño $A^{2}$, Juárez $A^{2}$, Frías $R^{3}$, Baz $P^{3}$, Tamez-Guerra $R^{1}$, Dehesa $M^{2}$. ${ }^{1}$ Facultad de Ciencias Biológicas, UANL; ${ }^{2}$ Centro Médico Nacional Siglo XXI, IMSS; ${ }^{3}$ Instituto Nacional de Cancerología, SS, México, D.F., México.

La infección persistente del virus de hepatitis C (HCV) causa una hepatitis crónica, la progresión hacia formas más graves como son cirrosis y carcinoma hepático se ha relacionado con el genotipo infectante de HCV especialmente el $1 \mathrm{~b}$. El propósito de este estudio fue investigar los genotipos de $\mathrm{HCV}$ en pacientes infectados con el virus del CMN siglo XXI con: hepatitis crónica (19), cirrosis (9) y cirrosis con carcinoma hepático (15), por dos métodos: PCR de la región "core" del virus con primers específicos para cada tipo y subtipo y detección de anticuerpos específicos contra epítopes específicos de grupo de la región NS4 del virus. La distribución de los genotipos en la población con hepatitis crónica fue la siguiente: 12 pacientes infectados con el genotipo $1 \mathrm{~b}(63.2 \%), 4$ pacientes con el genotipo 1a (21\%), 2 pacientes con el genotipo $3 \mathrm{a}$ 


\section{A García-Carrancá, RM del Angel, R Rivera-Torres.}

(10.5\%), y 1 paciente con el genotipo 2a (5.3\%). Con respecto al serotipo, obtuvimos 1 paciente con el tipo 2 que correspondió al genotipo $2 \mathrm{a}, 17$ pacientes con el tipo 1 y en un paciente no se obtuvo serotipo (cuyo genotipo fue $1 \mathrm{~b}$ ). La distribución de los genotipos en las poblaciones de cirrosis fue: 8 con genotipo $1 \mathrm{~b}(89 \%)$ y 1 con genotipo $1 \mathrm{a}$ (11\%) por PCR (los 9 fueron serotipo 1), en pacientes con carcinoma hepático: 14 con genotipo $1 \mathrm{~b}$ (93.3\%) y serotipo $1 \mathrm{y}$ en un paciente no fue posible obtener genotipo ni serotipo. Los datos encontrados corroboran la relación del genotipo $1 \mathrm{~b}$ de $\mathrm{HCV}$ con la progresión a formas graves. La concordancia de serotipo con genotipo fue del $95 \%$ lo que ofrece una ventaja para aplicaciones clínicas.

BAJA O NULA ACTIVIDAD CITOTOXICA DE LAS CÉLULAS NK-SOBRE CÉLULAS INFECTADAS CON CITOMEGALOVIRUS HUMANO. Sánchez-Cruz $\mathbf{P}^{1}$, Gil-Pérez JA ${ }^{1}$, Marroquín-Segura $\mathbf{R}^{2}$, Chacón-Salinas $\mathbf{R}^{1}$, Valdés-Espinosa $\mathbf{R A}^{1}$. ${ }^{1}$ Área de Inmunolgía, EMGS SDN; ${ }^{2}$ Lab. Inmunología, FES Zaragoza, UNAM, México, D.F., México.

Citomegalovirus humano (HCMV) es un patógeno ubicuo que causa infecciones crónicas y agudas. Los principales grupos de riesgo son los recién nacidos, los individuos transplantados y los pacientes con SIDA. El virus es capaz de disminuir la expresión de moléculas de clase I en la célula infectada, por lo que se ha sugerido que las células NK son las responsables del control de la infección, sin embargo, esta hipótesis no se ha apoyado experimentalmente.

Para evaluar la actividad citotóxica de las NK hacia células infectadas con HCMV, se utilizaron como blanco monocitos U-937 a las 96 hpi y fibroblastos MRC-5 a 96 y 288 hpi. La infección se evidenció por amplificación del gen IE-1 del virus. La disminución de la expresión de moléculas del MHC clase I se visualizó por citometría de flujo. Las células efectoras se obtuvieron de nueve donadores sanos a los cuales se les evaluó por ELISA la presencia de anticuerpos contra el HCMV. La población enriquecida de NK se obtuvó por selección negativa, identificando las NK por la expresión de CD16 y CD56. La citotoxicidad fue determinada por liberación y actividad de la enzima LDH después de $6 \mathrm{~h}$ de incubación de las células efectoras/blanco $(\mathrm{E} / \mathrm{T})$.

La población de NK se enriqueció hasta $80 \%$, su funcionalidad se demostró por la capacidad de lisar células K-562. En los monocitos y los fibroblastos infectados se detectó la presencia del DNA viral desde las $24 \mathrm{~h}$ y hasta las $72 \mathrm{~h}$ para los primeros y hasta las $288 \mathrm{~h}$ para los segundos. La expresión de moléculas de clase I se redujó en 50\% a las 96 hpi y en 70\% a las 288 hpi. Sólo en tres de los nueve donadores se observó actividad citotóxica a las 96 hpi, aunque baja ( $<20 \%$ en la relación E/T 60:1). A las 288 hpi tampoco se observó citotoxicidad en aquellos que no la mostraron a las $96 \mathrm{hpi}$, sin embargo, en un donador, (19\% de citotoxicidad a las 96 hpi) aumentó hasta $32 \%$ a las 288 hpi. En ninguno de los donadores se encontró IgM específica contra HCMV y cinco de nueve fueron seropositivos a IgG específica contra el virus. De los tres casos en que se observó citotoxicidad, dos correspondieron a individuos seropositivos y uno a un seronegativo contra IgG.

Estos resultados demuestran que las células NK tienen parcial o nula actividad citotóxica sobre las células infectadas por HCMV. Sin embargo es necesario evaluar otras funciones de las células NK (producción de citocinas), para establecer su participación contra la infección por HCMV.

INCREMENTO EN LA EXPRESIÓN Y FUNCIÓN DE CD95 EN MACROFAGOS INFECTADOS CON CITOMEGALOVIRUS HUMANO. Chacón-Salinas R, Sánchez-Cruz P, Suárez-Souto MA, Villalba-Magdaleno JD, Valdés-Espinosa RA. Area de Inmunología, Escuela Militar de Graduados de Sanidad, SDN, México, D.F., México.

El citomegalovirus humano (HCMV) es el miembro más representativo de los $\beta$-herpesvirus, que causa infecciones persistentes y latentes con períodos frecuentes de reactivación. Es una de las principales causas de morbilidad y mortalidad en individuos inmunosuprimidos e inmunocomprometidos, pero en huéspedes inmunocompetentes la infección cursa por lo general de forma asintomática. El control de la infección en el huésped está dado principalmente por los linfocitos citotóxicos, los cuales destruyen a las células infectadas a través de apoptosis inducida por exocitosis granular, o bien por medio de la activación de la molécula CD95. Recientemente se ha observado que HCMV tiene la capacidad de inhibir la apoptosis inducida por TNF- $\alpha$, dexametasona, proteínas virales, etc., por lo que en este trabajo se evaluó la funcionalidad de CD95 para inducir apoptosis en macrófagos infectados ín vítro con HCMV.

Como fuente de macrófagos se utilizaron monocitos de sangre periférica estimulados con concanavalina A o forbol 12-miristato 13-acetato. La caracterización de las células obtenidas con estas estimulaciones mostró que sufrían cambios morfológicos, aumento en la expresión de la molécula CD14, así como presencia de moléculas clase II del complejo principal de histocompatibilidad en relación con monocitos que no fueron estimulados. Posteriormente se observó que los macrófagos eran susceptibles de ser 


\section{Congreso Nacional de Bioquímica y Biología Molecular de Virus.}

infectados in vítro por HCMV, ya que presentaban DNA viral 5 días después de la infección inicial, así como expresar la proteína viral IE-1 desde las primeras 24 horas postinfección. La expresión de CD95 en la superficie de los macrófagos infectados por HCMV se encontró incrementada en relación con las células sin infectar. Al evaluar la funcionalidad de esta molécula se observó un incremento en la actividad de la misma cuando los macrófagos se encontraban infectados, sufriendo apoptosis la mayoría de ellos a las 72 horas postinfección cuando eran cultivados en presencia de un activador (antiCD95). Los resultados aquí ilustrados nos demuestran que HCMV es incapaz de interferir con la función de CD95, además de que nos permite sugerir que esta molécula puede desempeñar un papel muy importante en el control de infecciones virales, y en particular la provocada por HCMV.

CASOS FATALES DE FIEBRE HEMORRÁGICA POR DENGUE EN EL ESTADO DE MORELOS. Rangel $\mathbf{H}^{1}$, Figueroa $R^{1}$, Acosta $M^{1}$, Raga $E^{2}$, Ramos $C^{1}$. Area de Virología Molecular, CISEI/INSP, Cuernavaca, Mor.; ${ }^{2}$ Hospital General "José G. Parres", Cuernavaca, Morelos, México. (cramos@insp3.insp.mx).

En la última década ha ocurrido en México un incremento alarmante de casos de Fiebre Hemorrágica por Dengue (FHD), incluyendo casos fatales. Hasta 1995 habían circulado en el país los serotipos l, 2 y 4; la mayoría de los casos de FHD reconocidos hasta esa fecha, han sido causados principalmente por el serotipo 4 .

Durante mucho tiempo el serotipo 3 no se había reportado en la región de las Américas, sin embargo, a finales de 1995 se reconoció la transmisión de este serotipo en el sureste de México. En los siguientes años se diseminó por todo el país y durante los últimos 3 años la mayoría de los casos de FHD se asociaron con este serotipo. Frecuentemente el dengue-3 se asocia con casos de FHD en varios países del Sudeste Asiático.

En este trabajo describimos el estudio clínico de 3 casos fatales de FHD que ocurrieron en el Estado de Morelos durante 1998.

El cuadro clínico se clasificó de acuerdo a los criterios de la OMS y todos coincidieron con signos y síntomas compatibles con la enfermedad (fiebre, alguna manifestación hemorrágica, trombocitopenia, hemoconcentración, síntomas de choque, dolor abdominal, hepatomegalia, derrame pleural y alteraciones neurológicas). Pese al tratamiento médico implementado con soporte sistémico, el desenlace fatal en dos casos se debió a falla orgánica múltiple y el tercer caso presentó manifestaciones hemorrágicas con choque hipovolémico.

Se identificó el serotipo 3 en el suero de dos pacientes mediante RT-PCR y del tercer caso se aisló el virus en cultivo de células y está pendiente la tipificación. Los 3 pacientes tuvieron anticuerpos IgM e IgG que se detectaron mediante el ensayo de Inmunocromatografía Rápida (RIT, PanBio). Con el fin de conocer el posible origen de este virus, se discutirá la estrategia molecular para identificar el genotipo.

INFECCIONES CONCURRENTES CAUSADAS POR VARIOS SEROTIPOS DE VIRUS DENGUE. LoroñoPino MA ${ }^{1,2}$, Cropp $\mathrm{B}^{2}$, Farfán-Ale $\mathrm{JA}^{1,3}$, Vorndam $\mathrm{VA}^{4}$, Rodríguez-Angulo EM${ }^{1}$, Rosado-Paredes EP' ${ }^{1}$, FloresFlores $\mathrm{LF}^{1}$, Beaty $\mathrm{BJ}^{3}$, Gubler $\mathrm{DJ}^{2}{ }^{1}{ }^{1} \mathrm{CIR}$, Universidad Autónoma de Yucatán, Mérida, Yucatán; ${ }^{2} \mathrm{CDC}$, Ft. Collins, CO; ${ }^{3}$ AIDL, Colorado State University, Ft. Collins, Co; ${ }^{4}$ SJL, CDC, San Juan, PR.

La co-circulación de los cuatro serotipos de virus dengue en la misma región ha sido común desde los años de 1950 en el Sureste de Asia y en los últimos 20 años en muchas islas del Caribe, México, Centro y Sur América. La frecuencia de infecciones simultáneas por más de un serotipo en el mismo paciente (infecciones concurrentes) es más probable en estas áreas. El objetivo del proyecto fue el de determinar la frecuencia de infecciones concurrentes en epidemias donde se había documentado la co-circulación de múltiples serotipos de virus dengue. Se analizaron 292 especímenes de sueros virémicos y mosquitos inoculados con suero de pacientes colectados durante epidemias ocurridas en Indonesia, México y Puerto Rico. En 16 (5.5\%) de los 292 especímenes estudiados demostraron tener dos o más serotipos de virus dengue mediante las técnicas de inmunofluorescencia indirecta y/o RT-PCR. La probabilidad de dobles infecciones se ven aumentadas debido a que los mosquitos Aedes aegypti se alimentan en múltiples ocasiones durante un solo ciclo gonadotrópico. Recientemente se reportó evidencia de recombinación entre cepas de dengue-1. El papel que pudieran desempeñar tales cambios genéticos en la virulencia o el potencial epidémico de los virus del dengue es desconocido.

EFECTO DEL MICROAMBIENTE EN LA DIVERSIDAD DEL GENE prM DEL VIRUS DENGUE-4. Farfán-Ale $\mathrm{JA}^{1,2}$, Loroño-Pino $\mathrm{MA}^{1}$, Olson $\mathrm{KE}^{2}$, Beaty $\mathrm{BJ}^{2}$. ${ }^{1}$ Centro de Investigaciones Regionales, Universidad Autónoma de Yucatán, Mérida, Yucatán; ${ }^{2}$ AIDL, Colorado State University, Ft. Collins, CO.

El microambiente donde se desarrollan los virus con genoma de ácido ribonucleico (ARN) podría favorecer la emergencia de nuevas variantes virales, como resultado de su plasticidad genética. La mayoría de los virus con 


\section{A García-Carrancá, RM del Angel, R Rivera-Torres.}

genoma de ARN tienen muy altas tasas de mutación. Los virus del dengue naturalmente replican en dos huéspedes diferentes, humanos y mosquitos. La composición de las poblaciones virales en el suero de pacientes y en células C6/36 (obtenidas de Aedes albopíctus) podría ser diferente. Decidimos evaluar la composición de la población de virus en el suero de un paciente con dengue y del mismo virus después de dos pases en la línea celular C6/36, mediante el análisis del polimorfismo de cadenas únicas de ADN (SSCP) y la secuenciación nucleotídica de la región genómica prM de los virus y ADNC individuales obtenidos mediante clonación. Encontramos sustituciones de nucleótidos en 3 de 7 clonas que contenían ADNc de virus que fueron pasados en células C6/36. Las tres sustituciones estuvieron localizadas en la primera posición del codón. En las clonas obtenidas de virus del suero, encontramos sustituciones de nucleótidos en 4 de 6 clonas. De cinco remplazos, cuatro estuvieron localizados en la tercera posición del codón. La presencia de mutaciones nosinónimas en las clonas de los virus que habían sido cultivados en células sugiere la existencia de fuerzas selectivas en este microambiente que promueven el crecimiento de variantes virales.

INTERACCION DE FACTORES CELULARES CON LA RNT 3' DEL VIRUS DEL DENGUE SEROTIPO 4 De Nova-Ocampo M. $A^{1}$ y del Angel-Núñez R. Ma. ${ }^{2}$ ${ }^{1}$ Programa Múltidisciplinario de Biomedicina Molecular; ${ }^{2}$ Depto. de Patología Experimental, CINVESTAV-IPN, México, D.F. 07360, México.

Las regiones no traducidas (RNTS) de diversos virus de RNA se consideran regiones reguladoras de eventos como traducción, replicación, etc. Esta regulación está mediada generalmente por la interacción de estas regiones con factores celulares y/o virales. Distintas evidencias han mostrado que el dengue posee secuencias conservadas (CS1 CS2A y CS2B) que podrían ser el sitio blanco para la unión de factores celulares y/o virales. La eliminación o alteración de la estructura y/o secuencia de estas regiones tiene repercusiones drásticas a nivel de la traducción y/o replicación viral. Por ello decidimos analizar las posibles interacciones entre la RNT 3' de D4 con factores celulares y/o virales presentes en extractos S10 de la línea celular C6/36 infectada y no infectada. Por PCR generamos tanto la RNT 3' completa como el DNAc que contiene deleciones de las secuencias denominadas CS2A y CS2B. Mediante ensayos de retardamiento pudimos observar la formación de 4 complejos tanto en extractos de células no infectadas como infectadas con las diferentes regiones. Ensayos de superretardamiento con el anticuerpo anti EF-l $\alpha$ nos permitieron ver el superretardo de un complejo tanto con la región completa de D4 como con la región CS2A. Ensayos de entrecruzamiento-Western-blot nos permitieron definir la unión de una proteína de $50 \mathrm{kDa}$ a la región completa de $\mathrm{D} 4$ y a la región CS2A que comigra con una proteína detectada por WB con los anticuerpos contra el factor de elongación EF-1 $\alpha$. Así mismo detectamos unidas a la región completa una proteína de $52 \mathrm{kDa}$ que podría corresponder a la proteína La, así como dos proteínas una de $68 \mathrm{kDa} \mathbf{y}$ de $103 \mathrm{kDa}$ que por peso podrían corresponder a las proteínas virales NS3 y NS5 respectivamente.

SEROPREVALENCIA CONTRA EL VIRUS DE LA ENFERMEDAD DE BORNA (VEB) EN PACIENTES CON ESQUIZOFRENIA EN EL HOSPITAL PSIQUiátrico YUCATÁn DE LA SS. Puerto FI ${ }^{1}$, Zavala JE ${ }^{1}$, Ritter $\mathrm{K}^{2}$, Neufelder $\mathrm{C}^{2}$, Rosado-Franco $\mathrm{A}^{3}$, Baquedano-Lopez $\mathrm{G}^{3}$, de la Torre $\mathrm{JC}^{4}$. ${ }^{1}$ Universidad Autónoma de Yucatán, Yucatán; ${ }^{2}$ Rheinisch Westfälische Technische Hochschule, Aachen, Alemania; ${ }^{3}$ Hospital Psiquiátrico Yucatán SS, Yucatán; ${ }^{4}$ The Scripps Research Institute, La Jolla, USA.

El VEB es un viejo conocido que ahora tiene una nueva clasificación, es RNAss-, clasificado como una nueva familia, Bornaviridae, en el orden de los Mononegavirales. El VEB es un agente neurotrópico con capacidad de infectar a una gran variedad de mamíferos. La infección experimental ha demostrado que los virus tienen un gran rango clínico, que varía de una infección asintomática con estaciones en el transtomo de la conducta a una encefalomielitis fatal, dependiendo de la especie animal y edad estudiada. Recientemente se ha descrito que VEB infecta a los seres con problemas psiquiátricos o suprimidos, e incluso se han aislado virus de pacientes con trastornos psiquiátricos. El objetivo del presente estudio fue detectar sí existe la presencia de Ac's en pacientes con esquizofrenia. Se utilizó la técnica de Western-blot contra la proteína p24 completa obtenida del plásnúdo pGEX-5X-3 con-ío una proteína de fusión con GST y purificada con sefarosa 4B activada y proteasa Xa. Estos resultados fueron reconfirmados en Alemania y USA en donde se encontró una buena correlación, Incluso con IF. Se encontró que el $24 \%$ de los pacientes con esquizofrenia y el 3\% de los controles presentan Ac's. Estos resultados revelan que este virus puede estar ampliamente distribuido en el mundo y puede jugar un papel importante como un co-factor en la génesis de algunos trastornos psiquiátricos, ya que no sólo en la esquizofrenia se han identificado Ac's, sino en otros trastornos de la conducta como en la depresión. 


\section{Congreso Nacional de Bioquímica y Biología Molecular de Virus.}

VARIACIÓN GENÉTICA Y ANTIGÉNICA DE LA GLICOPROTEÍNA HN DEL VIRUS DEL SÍNDROME DEL OJO AZUL. Paniagua BN ${ }^{1}$, Cruz $\mathrm{CC}^{1}$, Santana $\mathbf{R H}^{1}$, Calderón TJ ${ }^{2}$, Hernández $\mathbf{H M}^{2}$, Tapia-Ramírez J. ${ }^{1}{ }^{1}$ Departamento de Genética y Biología Molecular, ${ }^{2}$ Departamento de Biología Celular CINVESTAV, IPN. México D.F. C.P. 07000, México.

A principios de 1980 se observó en granjas porcícolas de La Piedad Michoacán una enfermedad nueva, caracterizada por producir en los cerdos desórdenes en el sistema nervioso central, así como opacidad en la córnea; por esto último se le denominó síndrome del ojo azul (SOA). Más tarde un virus fue aislado a partir de cerebros de lechones que presentaban la enfermedad, este virus fue llamado VSOA o LPMV. Recientemente y de acuerdo al comité internacional de clasificación de virus éste fue ubicado dentro de la familia de los Paramyxovirus en el genero Rubulavirus. En 1991, caracterizarnos dos cepas del mismo virus a los que denominamos CI y CII que muestran diferencias en cuanto a: 1) virulencia sobre cultivos celulares 2) estequiometría de la proteína estructural (glicoproteína HN) y 3) en los ensayos de neutralización in vitro se encontró que un anticuerpo monoclonal dirigido contra la $\mathrm{HN}$ de la cepa CII es incapaz de proteger contra la cepa CI. Estos resultados sugieren que uno de los factores de patogenicidad puede estar dado por las diferencias en la glicoproteína $\mathrm{HN}$ del virus. Utilizando oligonucleótidos sintéticos específicos para el gen HN y mediante RT-PCR hemos clonado y determinado la estructura primaria del gen $\mathrm{HN}$, de una de las cepas, y analizamos qué cambios han ocurrido a lo largo de diez años, utilizando como cepa de referencia un aislado de 1981. Los resultados obtenidos hasta la fecha muestran cambios en varios aminoácidos; y por un análisis computacional, utilizando diferentes algoritmos, se demuestran cambios en la superficie externa de la proteína, lo cual probablemente implica cambios en la estructura antigénica de la $\mathrm{HN}$ del virus.

SEROPREVALENCIA DE ANTICUERPOS CONTRA EL VIRUS DE INFLUENZA PORCINA A H3N2 EN GRANJAS PORCÍCOLAS DE YUCATÁN, MÉXICO. Ayora-Talavera G, Rodríguez BJC, Alvarez FM, Víllegas PS, Canto CA, Bastarrachea VD. FMVZ. CIR"Dr. Hideyo Noguchi". Universidad Autónoma de Yucatán, Mérida, Yucatán, México.

Las infecciones de los cerdos con virus de influenza A son importantes para la industria porcina y en la epidemiología de los virus, de influenza A humanos. Desde 1976 se sabe que la influenza porcina (IP) puede ser transmitida de cerdos a humanos y causar enfermedades respiratorias agudas. Actualmente se desconoce la frecuencia de infección del virus de influenza porcino en Yucatán. Nuestro trabajo demuestra la prevalencia de anticuerpos contra el virus de influenza porcino A H3N2 (Ac-IP), en cerdos de engorda en granjas porcícolas del Estado de Yucatán. Se colectaron: muestras de sangre de cerdos de engorda de 25 granjas porcícolas del Estado con síntomas clínicos de infección respiratoria aguda. Se seleccionaron al azar de cada granja 38 a 42 cerdos distribuidos en las cuatro diferentes etapas: destete, crecimiento, desarrollo y finalizado, considerando una frecuencia de infección por IP $<8 \%$, un nivel de confianza de $95 \%$ y una población promedio de 2000 cerdos. La detección de Ac-IP se realizó utilizando la técnica de inhibición de la hemaglutinación. Se consideraron positivos aquellos sueros cuyos títulos fueran igual o mayor a 1:80. En total se estudiaron 1008 sueros de sendos cerdos y se encontraron Ac-IP a títulos 1:80 en 649 cerdos (prevalencia del 64.04\%). Las etapas con mayor número de cerdos positivos fueron desarrollo (168 cerdos) y finalizado (187 cerdos). Se demuestra por primera vez en el Estado de Yucatán la presencia de anticuerpos contra el virus de IP tipo A H3N2 y su participación dentro de las enfermedades respiratorias en cerdos. Así, la participación de los cerdos en la transmisión del virus de influenza a los humanos es un evento factible.

CARACTERIZACIÓN DE VIRUS DE LA BRONQUITIS INFECCIOSA DE LOS POLLOS AISLADOS EN AVES DE TRASPATIO EN YUCATÁN, MÉXICO. Gutiérrez-Ruiz EJ, Banks J, Gough RE. Deptos. de Virología de la FMVZ-UADY, México y la Agencia Central Veterinaria, MAFF, Reino Unido.

La bronquitis infecciosa es una enfermedad viral que afecta tanto a pollos en crecimiento como a gallinas ponedoras. Esta enfermedad causa graves pérdidas económicas a pesar del uso rutinario de vacunas. En estudios realizados en nuestro país se han identificado los tipos Masachussets, Connecticut y Arkansas del virus. El objetivo de este trabajo fue aislar el virus en aves de traspatio y determinar los tipos presentes en el estado. Se obtuvieron siete aislamientos del virus, seis de ellos en aves de traspatio y uno en granja comercial. Los aislamientos fueron caracterizados antigénicamente mediante las pruebas de inhibición de la hemoaglutinación y seroneutralización en embrión de pollo, utilizando antígenos y antisueros de 13 tipos reconocidos del virus. Se realizó también la caracterización genética mediante la reacción en cadena de la polimerasa y secuenciacion de 


\section{A García-Carrancá, RM del Angel, R Rivera-Torres.}

nucleótidos del gen que codifica la región 1 del peplómero.

De los siete aislamientos analizados, tres fueron clasificados como pertenecientes al tipo Connecticut tanto antigénica como genéticamente. Los otros cuatro aislamientos fueron antigénicamente diferentes a los 13 tipos de referencia y formaron dos grupos distintos. Mediante el análisis genético y comparación con las secuencias publicadas en los bancos genéticos, estos dos grupos resultaron diferentes, por lo que se determinó que son dos tipos nuevos del virus de la bronquitis infecciosa de los pollos. Estos dos tipos nuevos se denominaron SIN6 y UADY.

CARACTERIZACION MOLECULAR DEL VIRUS DE LA RABIA AISLADO DE SERES HUMANOS PARA LA IDENTIFICACION DEL RESERVORIO. Gómez-Sierra M, Hernández-Rodríguez G, MeléndezFélix A, Juárez-Islas VM, Velásco-Villa A. Instituto Nacional de Diagnóstico y Referencia Epidemiológicos, México, D.F., México.

A pesar que los casos de rabia humana han disminuido significativamente en el último decenio debido a los programas de vacunación masiva en perros, la enfermedad continúa siendo un problema de salud pública. La pobreza extrema y la marginación aunadas a la desinformación, son características comunes en los casos de encefalitis rábica en humanos que complican la obtención de datos precisos para inferir al reservorio del virus. Estos datos son de vital importancia para establecer medidas de control y prevención dirigidas a abatir la circulación del virus rábico en los reservorios identificados en la naturaleza y con esto disminuir el riesgo de infección al ser humano. Los propósitos del presente fueron: determinar los reservorios del virus involucrados en el mantenimiento enzóotico de la enfermedad por región e identificar a los transmisores al ser humano y animales de interés económico. Se usó un total de 217 muestras de seres humanos y otras especies, que fueron diagnosticadas como positivas a rabia por la técnica de inmunofluorescencia directa en el INDRE y LESPs. Los aislamientos fueron caracterizados molecularmente y comparados para definir cadenas de transmisión. Se identificaron como reservorios: perros, murciélagos hematófagos e insectívoros, zorrillos y zorros. En seres humanos se encontró la misma variante que en el perro en un $93 \%$ y en el porcentaje restante se detectaron variantes del virus presentes en reservorios silvestres como: murciélagos hematófagos e insectívoros y zorrillos. En bovinos y otras especies se detectaron variantes pertenecientes a murciélagos hematófagos, zorrillos; predominando la variante de perro.

\section{Revista Biomédica}

